\title{
Students' Satisfaction with Module II Academic Programs Offered by Public Universities in Mombasa: A Comparative Study
}

\author{
Benard Nyambaso Omwando, Ingari Boaz Ken \\ Business Studies Department - Jkuat Mombasa Cbd Campus \\ Chairman/Lecturer Business Studies Dept, Jomo Kenyatta University Of Agriculture And Technology, \\ Mombasa Cbd Campus.
}

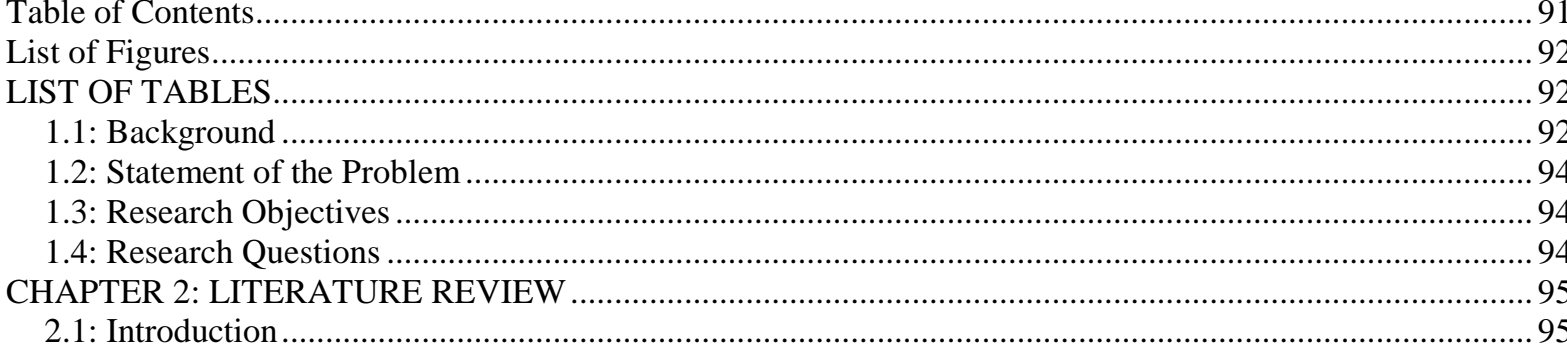

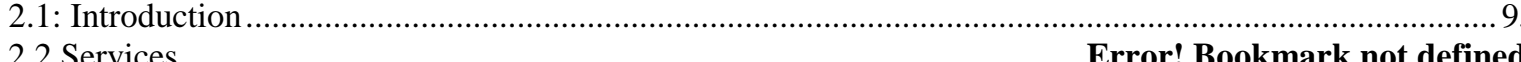

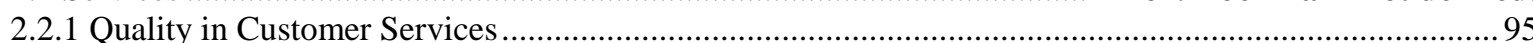

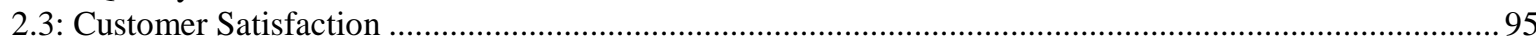

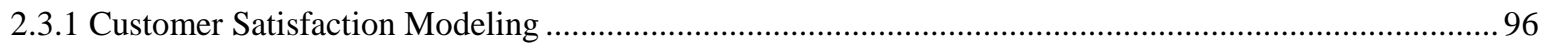

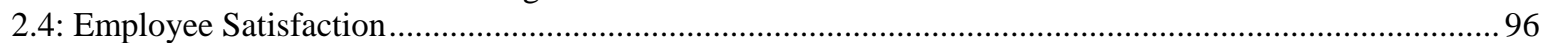

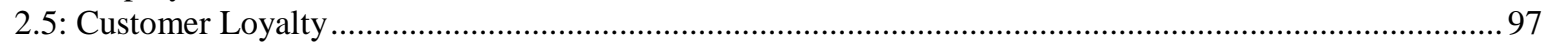

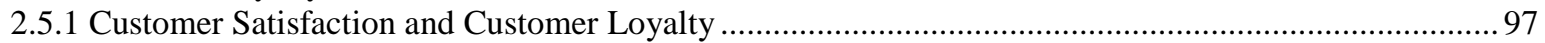

2.5.2 Service Satisfaction and Loyalty .................................................................... Bookmark not defined.

2.6: How Customer Satisfaction Impacts on Profitability .................................Error! Bookmark not defined.

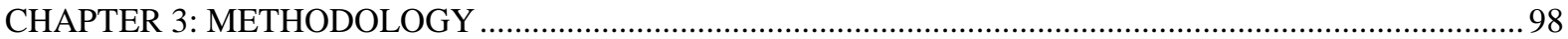

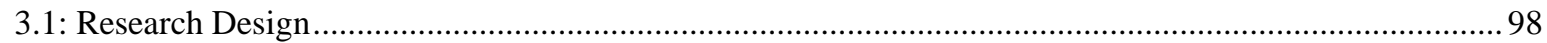

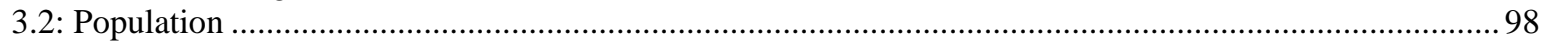

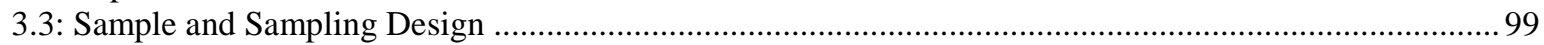

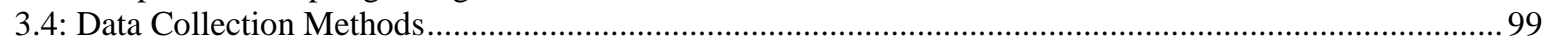

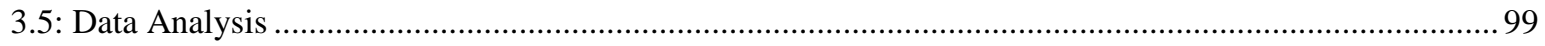

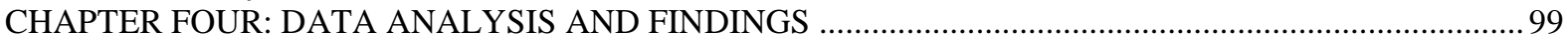

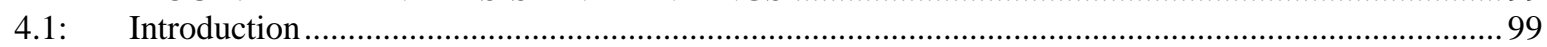

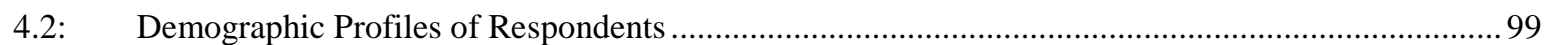

4.3 Perceived Customer Satisfaction levels of services offered by various universities .......................... 100

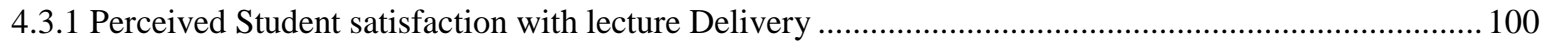

4.3.2 Perceived Student satisfaction with University Library and other resources ...................................... 101

4.3.3 Perceived Student satisfaction with University Facilities, furniture and other equipment .................... 102

4.3.4 Perceived Student satisfaction with University Tuition Costs.............................................................. 104

4.4 Satisfaction variables that need to be addressed to improve students' satisfaction ................................... 104

CHAPTER FIVE: SUMMARY, CONCLUSIONS AND RECOMMENDATIONS …............................... 105

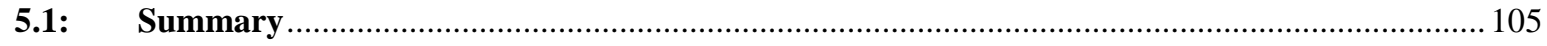

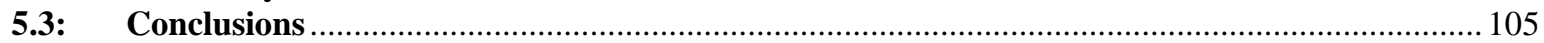

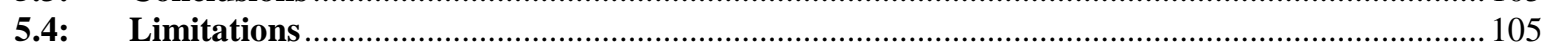

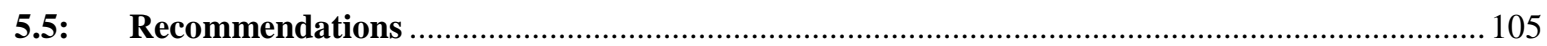

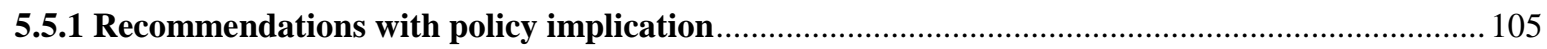

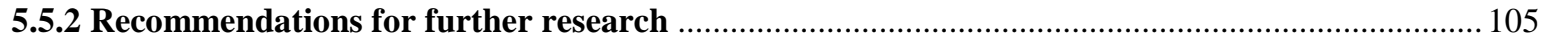

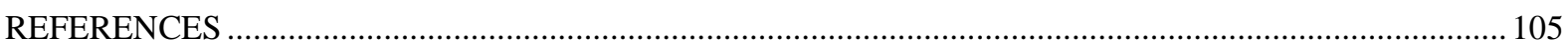

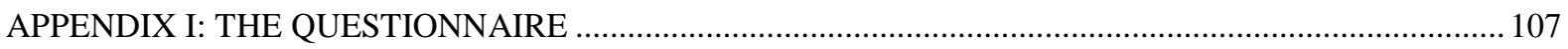

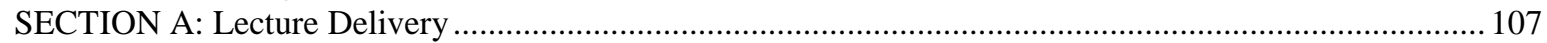

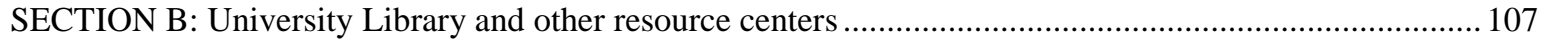




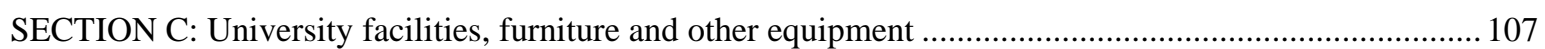

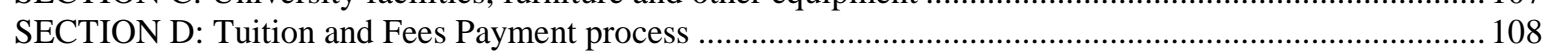

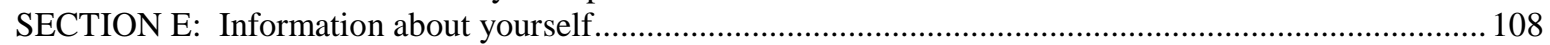

Figure 2.1: Elements of satisfaction-chain

\section{List of Figures}

Figure 2.2: Factors that Affect Customer Satisfaction............................................ Error! Bookmark not defined.

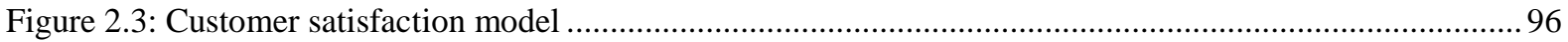

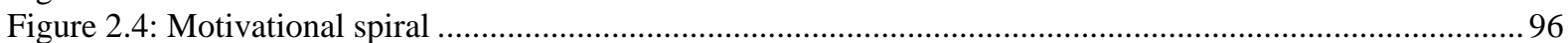

Figure 2.5: Conceptual framework of satisfaction, positive mood, value attainment, and loyalty (Ruyter and Bloemer, 1999, p. 327)

..Error! Bookmark not defined.

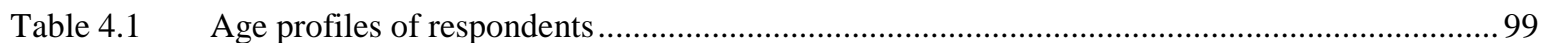

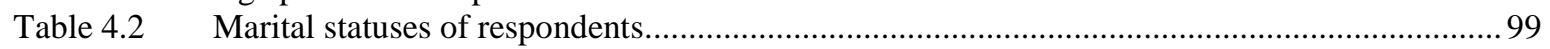

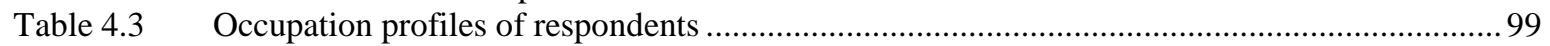

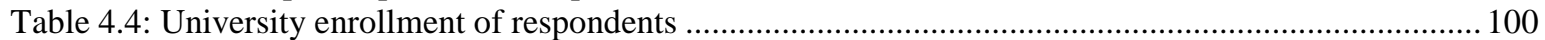

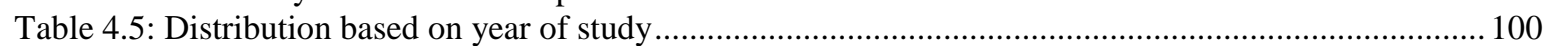

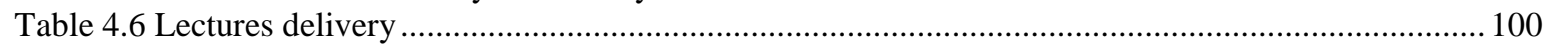

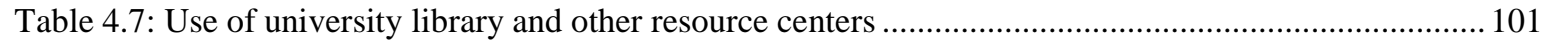

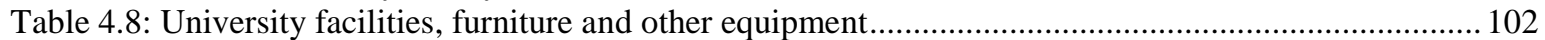

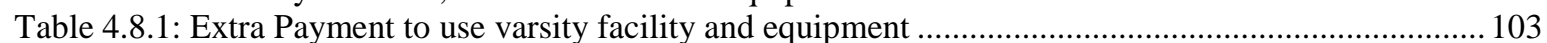

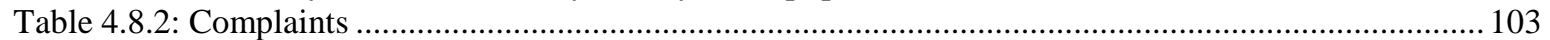

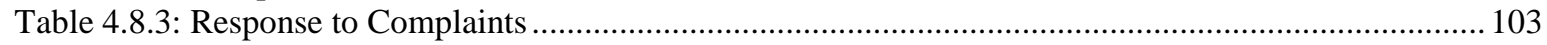

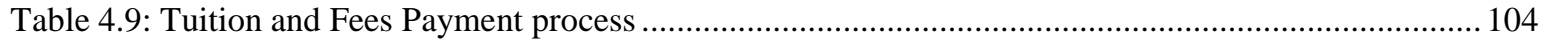

Abstract: Expansion of public universities through satellite campuses has burgeoned nationwide in Kenya. The promise of increased financial returns as a result of the subsequent increase in fee-paying students has proved irresistible to universities. However, the growth of these programs is carried out against a backdrop of few qualified teaching personnel, thereby increasing the lecturer-to-students ratio tremendously, amongst other key issues. The main objective of this study was to find out the comparative satisfaction levels of students enrolled in the Module II programs of public universities in Mombasa. The population of interest in this study was comprised of university students enrolled in the Module II program in public university satellite campuses in Mombasa, Kenya. The target population included all cadres of students including diploma, undergraduate, and post-graduate students from Kenyatta University, University of Nairobi, Moi University, and Jomo Kenyatta University of Agriculture and Technology.

From the study findings, students were generally satisfied with the services offered by the various campuses of public universities in Mombasa. There was a general consensus that the lecture delivery process across the various satellite campuses was flawless, and was conducted by experienced qualified personnel. There were minor differences in perceived levels of lecturer competence noted between members of various varsities. The findings further reveals that as much as the campuses offered good customer services at their libraries, plus the convenient timings for library use, the libraries were not fully stocked-up with enough learning resources. The study recommends that the universities make the following changes: Update their teaching/learning equipment with modern reliable ones for better service delivery. The study also recommends that the campuses upgrade their online journal systems to ensure easy and reliable access.

\section{1: Background}

\section{Introduction}

Governments in the world over grapple with the ever rising costs for public services. Consequently financing and expansion of the capacity of tertiary education systems, especially in low-income countries can only be met through cost-sharing. Cost-sharing is the shift of underlying costs from governments and taxpayers to parents and/or students. It is generally thought of as the introduction of, or especially sharp increase in, tuition fees to cover part of the costs of instruction or of user charges to cover more of the costs of lodging, food and other expenses of student living that may have hitherto been born substantially by governments (taxpayers) or institutions (Johnstone, 2003). Governments across the world have adopted different forms of cost-sharing to cover expenses associated with higher education. Some of the most straightforward and financially remunerative forms of cost-sharing, which are also more politically contested, include the introduction of tuition fees where they did not exist before, a great increase in tuition fees where they have already been established, and the 
introduction of the full user charges, or fees, on what may have previously been heavily subsidized accommodation and food.

The rationale for cost sharing has been subject of a large and well-accepted (even if politically and ideologically contested) body of economic and public finance theory (Johnstone, 2003, 2002, Woodhall, 2002, 1992). Australia, New Zealand, Scotland and UK share a system where tuition fees are deferrable for most students, as an income contingent loan to be repaid only after the student borrower is employed and earning a salary.

The introduction of so-called dual track, or parallel tuition fees (as in Kenya and Uganda), in which students who are not academically accepted into the small and selective pool of fully government-supported slots may still be admitted for a fee, maintains a kind of fiction of free higher education even though most young people, even the academically qualified, will never enjoy it (Johnstone, 2003). Governments and university leaders introduced dual track tuition policies in East Africa in order to expand higher educational capacity (and hopefully quality) without introducing politically unpopular tuition fees upon all students and families.

Table 1: Universities Student Enrolment by Mode of Study in, 2007, 2008

\begin{tabular}{|c|c|c|c|}
\hline Institution & JAB & Privately Sponsored & Total \\
\cline { 2 - 4 } Nairobi & 16,394 & 18,545 & 34,939 \\
\hline Kenyatta & 9,586 & 2,968 & 12,554 \\
\hline Moi & 9,208 & 5,455 & 14,663 \\
\hline Egerton & 10,702 & 1,467 & 12,169 \\
\hline JKUAT & 2,598 & 5,458 & 8,056 \\
\hline Maseno & 3,193 & 1,807 & 5,000 \\
\hline MMUST & 950 & 1,219 & 2,169 \\
\hline
\end{tabular}

Source: Commission for Higher Education

Table 1 above shows the university student enrolment by mode of study, in 2007 and 2008, into the seven public universities in Kenya. It is clearly evident that some public universities' main focus is on the module II (privately sponsored) program.Public universities now rely heavily on these Module II programs to steer their expansion and growth programs. In Kenya, the development and expansion of public universities has generally been through take-over of other tertiary institutions, most notably, teachers training colleges, regional polytechnics and other technical institutions. As Chacha (2004) observes, in 1984 the Moi University Act established that institution as a third national university. In late 1988, parliament made Jomo Kenyatta College of Agriculture and Technology a constituent college of Kenyatta University. It became an independent university through the Jomo Kenyatta University of Agriculture and Technology Act of 1994. Egerton, which offered diploma programs in agriculture, became a full-fledged university in 1988. Siriba Teachers' College became Maseno University College, a constituent college of Moi University, and later full-fledged Maseno University. Sergoit Teachers' College was transformed into Chepkoilel campus, which is a constituent college of Moi University. Laikipia and Kisii Teachers' Colleges both became campuses of Egerton University

Although Mombasa is the second largest city in Kenya, development of institutions of higher learning, particularly universities had remained a dream for a very long time. It was not until the expansion of the Module II programs, that universities started showing interest in the region. Public universities in Kenya used to depend fully on the government for funding for all their operations. In 1994, the government of Kenya decreased the education budget from 37 percent of its total annual recurrent budget to about 30 percent stating that it was not possible to allocate additional funding to higher education (Kiamba, 2004). This shortfall in the public budget for higher education brought about the impetus for institutions to look for alternative income generating sources, in an attempt to reduce their overdependence on the government budget. To this end, several strategies for revenue diversification were adopted including:

- Establishment of units for income generation. These include training and consultancy, university press and other units such as farms and even petrol stations (Kigotho, 2000).

- Institution of overhead charges: In some universities, individual professors with external research contacts must surrender 15 percent of the contract to the university.

- The introduction of the Module II (parallel track) programs in 1998.

The University of Nairobi was the first institution to offer Module II programs. The initial program involved degree programs in business studies only. Later, other subject specializations followed pursuit. Other public universities in the country started offering "parallel degree" programs afterwards as well.

Student admissions into the regular programs in public universities in Kenya are done through the Joint Admissions Board (JAB). In principle, KCSE holders with $\mathrm{C}+$ and above qualify for public university admission; however, this cut off point depends on total public university student capacity. Therefore, the JAB sets the entry for government-sponsored students from year to year. If a greater proportion of the students have 
high passes in a particular year, the cut off will be higher and vice versa (Marcucci, Johnstone and Ngolovoi, 2006). On the other hand entry, Module II students gain entry to universities on the basis of different criteria that vary from university to university. At the very initial stages of the Module II programs, "candidates had to be Form Four school leavers who met the minimum entry requirement of $\mathrm{C}+$ but could not meet the entry cut off point for government sponsorship. In an attempt to increase the number of self sponsored students, various institutions made admission conditions more flexible and accepted students from different academic backgrounds including holders of A level certificates, Kenya Advanced Certificate of Education (KACE) from the old 7-4-2-3 system, P1 holders, diploma holders, and certificate holders from other governmentallyrecognized institutions" (Otieno, 2004). However, trends for admission into Module II programs have changed. The majority of the students enrolled in the Module II program in Kenya's public universities currently earned higher grades in their KCSE exams than earlier believed. It is believed that many students prefer enrollment in the Module II program because it takes less time to finish degree programs in comparison with the Module I government-sponsored programs, which can be marred by interruptions and closures, forcing students to take substantially longer time periods to graduate. Additionally, many students appreciate the flexibility found in Module II, as they are able to attend classes after work and on weekends. However, the catch is usually in financing one's studies within the Module II program. In Kenya, the Module I (government sponsored) students pay tuition fees of about Kshs 16,000 (US\$200), while the Module II students pay about Kshs 150,000 (US\$2,000) and considerably more in some disciplines such as medicine. Module II classes run from $5.30 \mathrm{pm}$ through to $8.30 \mathrm{pm}$, Monday through Friday, and $8.00 \mathrm{am}-5.00 \mathrm{pm}$ on Saturdays and Sundays.

\section{2: Statement of the Problem}

Expansion of public universities through satellite campuses has burgeoned nationwide in Kenya. The promise of increased financial returns as a result of the subsequent increase in fee-paying students has proved irresistible to universities. These expansion programs are fuelled by the strong belief by most Kenyans that higher education is essential for competing for ever scarce job opportunities, and the unmet need for higher education institutions in the country. However, the growth of these programs is carried out against a backdrop of few qualified teaching personnel, thereby increasing the lecturer-to-students ratio tremendously, amongst other key issues.

It is against this backdrop that the study wishes establish the current satisfaction levels of the students in Mombasa who are admitted in the Module II programs. The choice of Mombasa specifically for this study is for convenience of researchers; and for the unique position of Mombasa, in that it is the only major city (and region) in the country not having a university offering regular (Module I) programs. Therefore all students admitted to all satellite campuses of all the public universities in the city are in the Module II program. The other interesting observation is that most of the students enrolled in this program are from relatively stable socio-financial backgrounds. As Otieno (2005) observes:

Survey data suggest that while students in both the module I and module II programs come from the better off segments of society, a significantly greater proportion of the students in the module II programs come from the richer segments of society and are concentrated in high and middle income families ( 89 percent) compared to students in the module I programs (68 percent)

\section{3: Research Objectives}

The main objective of this study is to find out the comparative satisfaction levels of students enrolled in the Module II programs of public universities in Mombasa. In particular, the study wishes to establish the following specific objectives:

1. To establish whether there are any significant difference in satisfaction levels between students enrolled in Module II programs in various satellite campuses of various public universities in Mombasa.

2. To identify the main satisfaction variables that need to be addressed to improve student satisfaction levels in various satellite campuses of various public universities in Mombasa.

\section{4: Research Questions}

From the research objectives, it is evident that the following questions will arise:

1. Is there any significant difference in satisfaction levels between students enrolled in Module II programs in various satellite campuses of various public universities in Mombasa?

2. What are the main satisfaction variables that need to be addressed to improve student satisfaction levels in various satellite campuses of various public universities in Mombasa? 


\section{1: Introduction}

\section{Literature Review}

Chapter two deals with the theoretical body of knowledge related to customer satisfaction in the service industry, and in higher education institutions in particular. The main idea of this chapter is to focus on theories of the satisfaction-profit chain (Anderson and Mittal, 2000). The conceptual framework of the study expands on linkages of service attributes to customer satisfaction, customer satisfaction to customer loyalty, and customer loyalty to profitability in institutions of higher learning. The connection between service-performance to profitability is covered by studying individual elements of the satisfaction-profit chain. The main idea of this chapter is that by improving product and service attributes, customer satisfaction should improve. Improved customer satisfaction is expected to lead to greater customer loyalty, which in turn leads to greater profitability. All this is not often evident, as the links in the satisfaction-profit chain are asymmetric and non-linear (Anderson and Mittal, 2000).

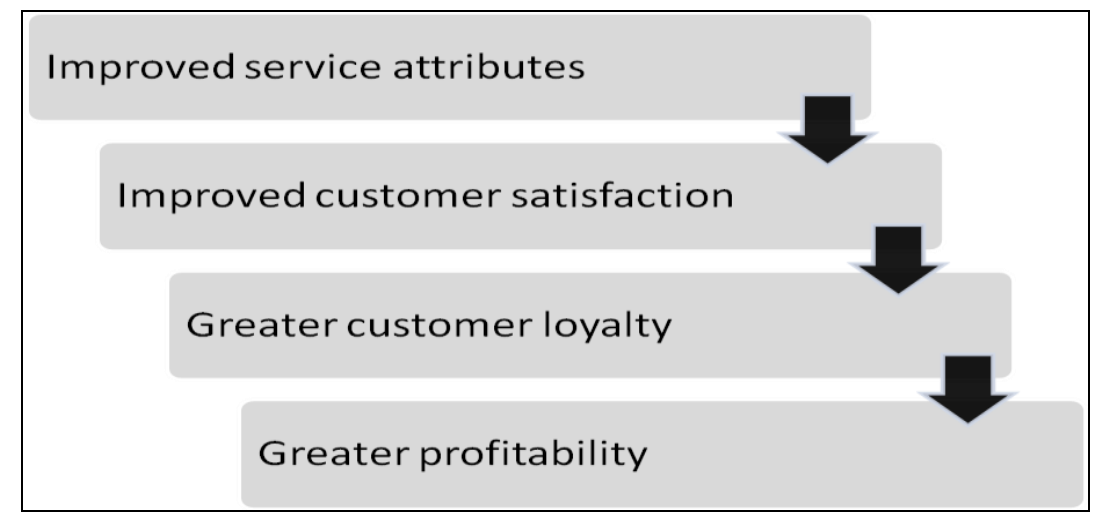

Figure 2.1: Elements of satisfaction-chain

\subsubsection{Quality in Customer Services}

Quality service starts with customer service. Customer service is viewed as a process that takes place between a buyer, a seller, and third party (Innis and La Londe, 1994). The customer drives the service process and defines the quality (Friday and Cotts, 1995). Previous studies have shown that customer service is an integral and necessary part of the marketing mix, and it offers a significant opportunity for companies to gain advantage in the market place (Sterling and Lambert, 1987, Lambert and Harrington, 1989). Higher levels of customer service can create customer loyalty and improve long-term sales and profitability of a supplier. Companies that think about improving customer service should engage in it only if they can expect adequate returns for their attempts (Bowersox and Closs, 1996). Eckert and Goldsby (1997) propose that the constructs of involvement and visioning could be used as predictors of a company's propensity to consider service improvements. High involvement and high visioning customers can be identified as a potential group that would be more likely to respond to improved customer service with increased customer loyalty. If a supplier opts to improve customer service, it should be based on difficult-to-imitate competencies in order to avoid negation of the competitive advantage.

\section{3: Customer Satisfaction}

Kotler (2000) defines customer satisfaction as follows:

Satisfaction is a person's feelings of pleasure or disappointment resulting from comparing a product's perceived performance (or outcome) in relation to his or her expectations.

Brown (1992) defines customer satisfaction as:

The state in which customer needs, wants and expectations throughout the product or service's life are met or exceeded resulting in repeat purchase, loyalty and favorable worth-of mouth.

The concept of customer value suggests a strong relationship with customer satisfaction (Woodruff, 1997). According to Parasuraman (1997), to create superior value continuously for a buyer requires that a supplier understand the buyer's entire value chain. Attributes that motivate a customer's initial purchase may differ from the criteria later (Woodruff, 1997). According to Parasuraman (1997), deficiencies that drive customers away may occur for other attributes than those that attract and retain the customers. In addition, Reichheld (1996) assumes that things that satisfy customers may not always be the same as those that create customer loyalty.

According to Zeithaml et al. (1996), companies should first examine the impact of service quality on customers' responses by asking them the following questions: What is the level of quality a supplier must deliver in order to keep the customer; what would encourage the customer to recommend the supplier; what factors would reduce 
the likelihood of a customer spreading negative worth-of-mouth; and should the supplier focus on proactive service improvements or on complaint handling in order to keep the customer.

Based on the research by Oliver (1993), it appears that positive and negative effects have independent effects on customer satisfaction. When considering product and service quality, product quality tends to be related to customer dissatisfaction and service quality is more related to the customer satisfaction. In general, there appear to be two categories of factors: hygiene and satisfier attributes. Hygiene factors contribute to customer dissatisfaction and satisfiers contribute to customer satisfaction. High levels of customer satisfaction resulted from the delivery of satisfiers. To delight a customer, a company's performance in hygiene factors must be adequate and combined with high performance in satisfiers (Naumann, 1994, Peck, 1997).

According to Finkelman and Goland (1990), companies need to develop a detailed understanding of customers' expectations in each stage of their ownership experience, develop supporting procedures and establish evaluation and incentive systems in order to satisfy customers. Wellington (1995) divides customer satisfaction elements into product, sales, after-sales, location, time, and culture. The satisfaction elements of after-sales include maintained interest and complaint handling. Complaint handling should be responsive and keep the customer advised through the process; a customer should feel appreciated. A customer's reordering should be made easy and it should build on existing information about the customer.

\subsubsection{Customer Satisfaction Modeling}

The nature of customer care is very much service oriented as most goods are consumed at the same time as services are experienced. To satisfy a customer, the supplier needs to have the services that the customer requires (Davidow, 1986). If the customer perceives a service in a certain way, but expected less, then the customer is satisfied, as the formula in Figure 2 shows. People and organizations that use professional services are traditionally prepared to pay high fees for the services, because of the uncertainty, importance, and risk involved. The customer wants to know that they get the required attention. A service firm that is able of project a caring image and backing that image with substance is likely to success (Maister, 1997).

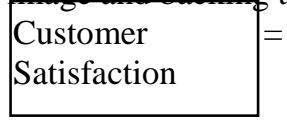

\begin{tabular}{|l|l|}
\hline $\begin{array}{l}\text { Customer } \\
\text { Perception }\end{array}$ & $=\quad \begin{array}{l}\text { Customer } \\
\text { Expectation }\end{array}$ \\
\hline
\end{tabular}

Figure 2.3: Customer satisfaction model

The customer anticipates how the service will be performed and that is added to his/her expectations. Customers have previous experiences and, based on those experiences, customers expect a service to be delivered in a certain way, which can be considered company-controlled expectations creators. Uncontrollable creators are actions of the competition and word of mouth.

Over time these company controllable and uncontrollable expectations creators together form the customer's standards. Customers compare services according to certain standards with which they are familiar and those do not necessarily relate to the service that is performed (Barsky, 1995, Friday and Cotts, 1995 and Oliver, 1996).

\section{4: Employee Satisfaction}

According to Heskett et al. (1990, 1994 and 1997), employee satisfaction drives customer satisfaction and customer intentions to continue to use services, as for example in the telecommunications with American MCI Communications, where a statistically significant relationship between these factors has been found. In Figure 3, the motivational spiral describes the link between employee motivation and performance. Heskett $e t$ al. (1997) describe this relationship between customer satisfaction and employee satisfaction as a mirror that reinforces positive relationships between customer and employee. High morale leads into economic success. On the other hand, failure in the marketplace leads to low motivation (Heskett et al. 1990, Maister, 1997).

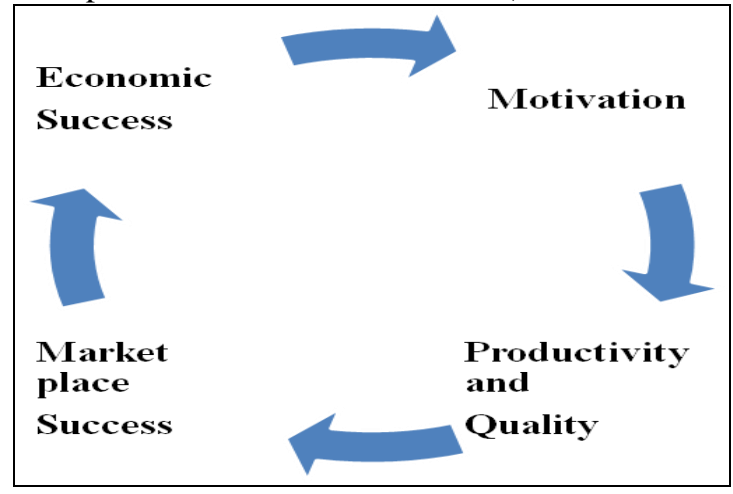

Figure 2.4: Motivational spiral 
A low employee turnover reduces the need to hire new employees and therefore company gets a better return on their personnel investments. Frequently, measures of employee turnover concentrate on costs of recruiting and training, but employee turnover results in a loss of productivity and decreased customer satisfaction. Psychological compatibility should be taken into account in recruiting. Particularly in the service industry, people are an important asset of a company. Caring about the customer is a by-product of internal relationships and culture. The way customers are treated is closely linked to the way employees feel about their jobs and work environment and is reflected in the morale, motivation, and turnover of employees. Common reasons for losing good employees include the company's setting of high standards without providing the tools and capabilities to achieve those expectations. (Riggs, 1983, Wellemin, 1984, Brown, 1992, Järvelin et al., 1992, Glanz, 1994, Heskett et al., 1994 and 1997, Petrozzo and Stepper, 1994, Barsky, 1995, Griffin, 1995, Morris, 1996, Maister, 1997, Reichheld, 1997).

As employees are the service providers to the customer, they have to be taken good care of. This includes fostering personal development, providing empowerment and pay in relation to achieved outcomes, as well as necessary time, tools, and support (Griffin, 1995, Heskett et al., 1997). Grant and Schlesinger (1995) note that the difference in productivity of the top-level performers compared to average or low-level performers could be quite large, which highlights the importance of recognition of top-performers.

Customers and employees evaluate a company's recent performance similarly on dimensions that are important for the customers: ease of doing business, competence of service people, timeliness of the service, service representatives' availability, and interest displayed by service personnel in helping customers. Customer service personnel may be in the best position to collect data from customers and organize it into information (Heskett et al., 1997). According to Brown (1992), frontline employees can predict with 90 per cent accuracy the timing and the nature of customer complaints. Frequently, customers and employees agree about a service problem.

High performing (Barker, 1999) salespeople are more innovative, more fulfilled by their jobs, more loyal, and more willing to take risks than low performance salespeople. In non-selling behavioral performance constructs, the high performance sales force appears to be more willing to accommodate customer's needs, which is likely to give them a competitive edge in building long-term relationship. On the whole, it is unlikely that everyone in a company will have the same view of the customer (Saunders, 1999).

\section{5: Customer Loyalty}

Oliver (1996) defines customer loyalty as follows:

Customer loyalty is a deeply held commitment to re-buy or re-patronize a preferred product or service consistently in the future, despite situational influences and marketing efforts having the potential to cause switching behavior.

According to Liljander and Strandvik (1992), customer satisfaction and repurchase intentions correlate positively. They found that it may be more beneficial to concentrate on influencing customers' experiences than altering their expectations in their research set-up.

Reichheld and Sasser (1990) and Reichheld (1996) have studied customer lifetime value and the value of building customer loyalty by listening to their complaints, anticipating their defection, and understanding why customers move to competitors. Customers remain loyal because of the value they receive from the supplier. Customer retention means continuing an active relationship with a customer (Cannie, 1994, Naumann, 1994, Heskett et al., 1997, Burgeson, 1998, Clemmet, 1998).

Zeithaml et al. (1996) states that recent research offers some evidence that service quality and customer satisfaction positively affect the customer's behavior. Customers, who have no service problems have the strongest levels of loyalty intentions. Nevertheless, their intentions to pay more are not significantly higher than customers who are experiencing service problems that are solved satisfactorily. Therefore, companies willing to improve services, particularly beyond the desired service-level, should do so in a cost-effective manner.

Companies aiming for customer loyalty tailor their offerings to customers to fit customer demands. Products or services are delivered to customers with minimal inconvenience and at competitive prices. Fulfilling customer demands can be expensive, but these companies typically look at the lifetime value of the customer. The customer may additionally have to pay extra for premium service (Treacy and Wiersema, 1993; Wiersema, 1998, Anderson and Mittal, 2000).

\subsubsection{Customer Satisfaction and Customer Loyalty}

Customer satisfaction means that the customer's needs are met, product and services are satisfactory, and customers' experience is positive (Friday and Cotts, 1995, Gitomer, 1998).

According to the definition, customer is satisfied when only minimum has been done for the customer. If a customer is said to be satisfied or happy about a purchase, the customer's overall feeling and experiences must be neutral or positive. Customer satisfaction itself is not an indication that there will be customer retention. A 
loyal customer is a customer whose expectations are met or exceeded and they proactively refer the supplier. The nature of loyalty has changed over time in society; nowadays it is based on mutually earned loyalty by the continued delivery of superior value to the customer. Customer loyalty can be measured and analyzed to minimize customer turnover and to increase the growth of key accounts. Griffin (1995) defined a loyal customer as a customer who regularly repeat purchases, purchases across product and service lines, has some level of immunity to competitors, and refers to others (Gouillart and Sturdivant, 1994, Hepworth and Mateus 1994, Wellington, 1995, Reichheld, 1997, Dickey 1998, Gitomer, 1998).

Kaplan and Norton (1996) propose that managers should have a clear idea of their targeted customers and a specific set of core outcome measurements such as customer satisfaction, retention, and profitability. Customer satisfaction measurements have frequently yielded results suggesting that the relationship between customer satisfaction and customer loyalty is not constant.

According to recent research, this link has proven to be the least reliable. Aggressive pricing policies could lure customers away from excellent service providers, which can affect short-term measures (Heskett $e t$ al., 1997).

Hallowell's study (1996) illustrates the potential impact of customer satisfaction on profit in the banking industry. Analysis provides an indication of the increase in profit resulting from an improvement in customer satisfaction, where the causality hypothesized in the service management literature exists. Hallowell (1996) states that the relationship among customer satisfaction, customer loyalty, and profitability warrants further research.

According to Ruyter and Bloemer (1999), the relationship between loyalty and satisfaction has remained equivocal. This may be even truer for services that are delivered over longer periods.

Oliva et al. (1992) argue that the relationship between service satisfaction and customer loyalty is non-linear. Anderson and Mittal (2000) argue that the links between customer satisfaction and customer retention can have asymmetric and non-linear aspects. Heskett et al. (1994 and 1997) propose that job satisfaction and customer satisfaction are closely related. Furthermore, Heskett et al. (1997) claim that there is direct and strong relationship between profit, growth, customer loyalty, customer satisfaction, value of the goods and services delivered to customers, and employee capability, satisfaction, loyalty, and productivity. Oliver (1996) also states that quality, satisfaction, and loyalty have an impact on profits. Ruyter and Bloemer (1999) in their attempt to extend knowledge about loyalty in services by including value attainment as a factor, argue that, in cases of relatively high levels of satisfaction, satisfaction would be the most important determinant of customer loyalty. However, in cases of extended service encounters, it may not always be possible to attain high levels of satisfaction.

Extended service encounters (Price et al., 1995) have the following characteristics as they represent interpersonal relationships: duration, an affective or emotional content, and the spatial proximity of service provider and customer. In these encounters, value attainment and positive mood may have an additional impact on customer loyalty intentions (Ruyter and Bloemer, 1999). Nevertheless, Ruyter and Bloemer (1999) studied the simultaneous effects of satisfaction, value attainment, and mood on customer loyalty, as there is some empirical evidence of an interaction effect among value attainment, mood, and consumer evaluations of the service experience. The relative importance of value attainment is considered to be greater than the that of mood and therefore it is likely that value attainment similarly has a stronger impact on the satisfaction-loyalty relationship than mood. However, more research is required on the conceptual difference between satisfaction and mood.

\section{1: Research Design}

\section{Methodology}

This research adopted a cross sectional descriptive research design. A simple descriptive research design is used when data are collected to describe persons, organizations, settings, or phenomena. This design is used to describe the characteristics of certain group e.g. age, income of certain group of people who are users of a particular product, etc, which are measured at a single point of time. Knupfer et. al., (2003) states that a study concerned with the: who, what, when, and how of a phenomenon is a descriptive study. The proposed study is concerned with customer satisfaction of students who are enrolled in the module II program of public universities in Mombasa.

\section{2: Population}

The population of interest in this study was comprised of university students enrolled in the Module II program in public university satellite campuses in Mombasa, Kenya. The target population included all cadres of students including diploma, undergraduate, and post-graduate students from Kenyatta University, University of Nairobi, Moi University, and Jomo Kenyatta University of Agriculture and Technology. 


\section{3: Sample and Sampling Design}

The universe in this case is defined as the entire population of university students enrolled in Module II programs in all public universities in Mombasa, Kenya. Convenience sampling was used for the purpose of the study. The researchers wished to come up with a convenient sample of 100 students for the study.

\section{4: Data Collection Methods}

Primary data was collected using a semi-structured questionnaire which was self administered (see Appendix I). The respondents were required to fill in the questionnaire as the researchers waited. The researchers's presence was thought to be helpful incase respondents needed clarification on any of the questions. The questionnaires were be pre-tested before fieldwork commences to test for clarity.

The questionnaire was divided into five parts. Questions were structured on a Likert scale. Section A was concerned with lecture delivery. Section B assessed university library and other resource centers in terms of whether they meet and/or exceed the students' expectations or if they fall below the expectations. Section C was on university facilities, furniture and other learning equipment. Section D focuses on tuition and the fees payment process. Section E was on personal information. Lastly, Section E focused on personal data of respondents.

\section{5: Data Analysis}

As informed by the theoretical and conceptual framework, our study findings required both descriptive and quantitative analysis. Findings were presented through use of charts, percentages, graphs and tables.

\section{1: $\quad$ Introduction}

\section{Data Analysis And Findings}

This section presents the findings of the study. The first section presents the demographic summary of the respondents and main services they received from their respective universities. This is followed by the results on the analysis of the perceived quality of customer service by the students from the various satellite campuses of the public varsities in Mombasa.

\section{2: $\quad$ Demographic Profiles of Respondents}

The demographic characteristics of the respondents analyzed include age, marital status, and occupation type. The findings are presented in the tables below.

Table 4.1 Age profiles of respondents

\begin{tabular}{rrrr}
\hline & Frequency & Percent & Cumulative Percent \\
\hline $18-24$ & 52 & 52.0 & 52.5 \\
$25-34$ & 33 & 33.0 & 85.9 \\
$35-49$ & 12 & 12.0 & 98.0 \\
50 and above & 2 & 2.0 & 100.0 \\
\hline
\end{tabular}

As shown in Table 4.1, majority of the respondents were aged between $18-24$ years, followed by the $25-34$ year bracket. This is a true reflection of the general age group of students in institutions of higher learning, with a cumulative $85.9 \%$. Of the 100 respondents, only two were aged 50 years and above. It is however worth noting that the number of students from this age bracket (ages 50 years and above) is notably growing.

Table 4.2 Marital statuses of respondents

\begin{tabular}{rrrr}
\hline & Frequency & Percent & Cumulative Percent \\
Single & 63 & 63.0 & 63.6 \\
Married & 34 & 34.0 & 98.0 \\
Other & 2 & 2.0 & 100.0 \\
Total & 99 & 99.0 & \\
\hline
\end{tabular}

According to Table 4.2 below $63.0 \%$ of the respondents were single, $34 \%$ were married and only $2.0 \%$ were divorced, widowed or otherwise.

The respondents were asked to indicate their occupation. The results are shown in Table 4.3.

Table 4.3 Occupation profiles of respondents

\begin{tabular}{rrrr}
\hline & Frequency & Percent & Cumulative Percent \\
formal employment & 42 & 42.0 & 42.9 \\
self-employed & 21 & 21.0 & 64.3 \\
casual labor & 4 & 4.0 & 68.4 \\
Other & 31 & 31.0 & 100.0 \\
Total & 98 & 98.0 & 0 \\
\hline
\end{tabular}


42 per cent of the respondents were in formal employment, 21 per cent were self-employed, with only 4 per cent in part-time employment. 31 per cent of the respondents were not in any form of employment.

Table 4.4: University enrollment of respondents

\begin{tabular}{rrrr} 
& Percent & Cumulative Percent \\
\hline JKUAT & Frequency & 10.0 & 10.1 \\
University of Nairobi & 10 & 24.0 & 34.3 \\
Kenyatta University & 24 & 24.0 & 58.6 \\
Moi University & 24 & 26.0 & 84.8 \\
MPUC & 26 & 15.0 & 100.0 \\
Total & 15 & 99.0 & \\
\hline
\end{tabular}

Table 4.4 above shows the distribution of the respondents based on university enrolled in.

Table 4.5: Distribution based on year of study

\begin{tabular}{rrrrr}
\hline & Frequency & Percent & Cumulative Percent \\
year one & 10 & 10.0 & 10.1 \\
year two & 54 & 54.0 & 64.6 \\
year 3 & 28 & 28.0 & 92.9 \\
year four & 4 & 4.0 & 97.0 \\
masters year one & 3 & 3.0 & 100.0 \\
Total & 99 & 99.0 & \\
\hline
\end{tabular}

Table 4.5 shows the distribution of respondents based on their year of study in their various institutions.

\subsection{Perceived Customer Satisfaction levels of services offered by various universities}

The first objective of the study was to establish whether there was any significant satisfaction levels between students enrolled in Module II programs in various satellite campuses of various public universities in Mombasa. The respondents were asked to enter their responses on agreement or disagreement with various statements related to their respective varsity's service delivery.

\subsubsection{Perceived Student satisfaction with lecture Delivery}

Table 4.6 Lectures delivery

\begin{tabular}{|c|c|c|c|c|c|c|c|c|}
\hline & Statements & Institution & $\begin{array}{l}\text { Strongly } \\
\text { Agree }\end{array}$ & Agree & Neutral & Disagree & $\begin{array}{l}\text { Strongly } \\
\text { Disagree }\end{array}$ & $\begin{array}{l}\text { Total } \\
\text { Percentage }\end{array}$ \\
\hline \multirow[t]{5}{*}{1.} & \multirow{5}{*}{$\begin{array}{l}\text { Lecturers came } \\
\text { on time }\end{array}$} & JKUAT & $10 \%$ & $40 \%$ & $30 \%$ & $20 \%$ & 0 & $100 \%$ \\
\hline & & $\begin{array}{l}\text { University of } \\
\text { Nairobi }\end{array}$ & $20.8 \%$ & $50 \%$ & $25 \%$ & $4.2 \%$ & 0 & $100 \%$ \\
\hline & & $\begin{array}{l}\text { Kenyatta } \\
\text { University } \\
\end{array}$ & $8.3 \%$ & $54.2 \%$ & $20.8 \%$ & $16.7 \%$ & 0 & $100 \%$ \\
\hline & & Moi University & $19.2 \%$ & $34.6 \%$ & $34.6 \%$ & $11.5 \%$ & 0 & $100 \%$ \\
\hline & & MPUC & $6.7 \%$ & $46.7 \%$ & $33.3 \%$ & $6.7 \%$ & $6.7 \%$ & $100 \%$ \\
\hline \multirow[t]{5}{*}{2.} & \multirow{5}{*}{$\begin{array}{l}\text { Lecturers treated } \\
\text { me fairly }\end{array}$} & JKUAT & $30 \%$ & $50 \%$ & $20 \%$ & 0 & 0 & $100 \%$ \\
\hline & & $\begin{array}{l}\text { University of } \\
\text { Nairobi }\end{array}$ & $29.2 \%$ & $62.5 \%$ & $8.3 \%$ & $\overline{0}$ & $\overline{0}$ & $100 \%$ \\
\hline & & $\begin{array}{l}\text { Kenyatta } \\
\text { University }\end{array}$ & $33.3 \%$ & $45.8 \%$ & $16.7 \%$ & 0 & $4.2 \%$ & $100 \%$ \\
\hline & & Moi University & $30.8 \%$ & $42.3 \%$ & $15.4 \%$ & $3.8 \%$ & $7.7 \%$ & $100 \%$ \\
\hline & & MPUC & $6.7 \%$ & $60.0 \%$ & $13.3 \%$ & $13.3 \%$ & $6.7 \%$ & $100 \%$ \\
\hline \multirow[t]{5}{*}{3.} & \multirow{5}{*}{$\begin{array}{l}\text { Lecturers were } \\
\text { knowledgeable } \\
\text { and competent }\end{array}$} & JKUAT & $20 \%$ & $50 \%$ & $30 \%$ & 0 & 0 & $100 \%$ \\
\hline & & $\begin{array}{l}\text { University of } \\
\text { Nairobi }\end{array}$ & $50 \%$ & $33.3 \%$ & $16.7 \%$ & 0 & 0 & $100 \%$ \\
\hline & & $\begin{array}{l}\text { Kenyatta } \\
\text { University } \\
\end{array}$ & $45.8 \%$ & $41.7 \%$ & $4.2 \%$ & $8.3 \%$ & 0 & $100 \%$ \\
\hline & & Moi University & $46.2 \%$ & $23.1 \%$ & $23.1 \%$ & $7.7 \%$ & 0 & $100 \%$ \\
\hline & & MPUC & $13.3 \%$ & $46.7 \%$ & $33.3 \%$ & $6.7 \%$ & 0 & $100 \%$ \\
\hline \multirow[t]{5}{*}{4.} & \multirow{5}{*}{$\begin{array}{l}\text { Lecturers were } \\
\text { fully prepared to } \\
\text { deliver }\end{array}$} & JKUAT & $20 \%$ & $70 \%$ & $10 \%$ & 0 & 0 & $100 \%$ \\
\hline & & $\begin{array}{l}\text { University of } \\
\text { Nairobi }\end{array}$ & $33.3 \%$ & $41.7 \%$ & $25 \%$ & 0 & 0 & $100 \%$ \\
\hline & & $\begin{array}{l}\text { Kenyatta } \\
\text { University } \\
\end{array}$ & $20.8 \%$ & $45.8 \%$ & $12.5 \%$ & $16.7 \%$ & $4.2 \%$ & $100 \%$ \\
\hline & & Moi University & $30.8 \%$ & $42.3 \%$ & $19.2 \%$ & $7.7 \%$ & 0 & $100 \%$ \\
\hline & & MPUC & $6.7 \%$ & $26.7 \%$ & $53.3 \%$ & $13.3 \%$ & 0 & $100 \%$ \\
\hline \multirow[t]{3}{*}{5.} & \multirow{3}{*}{$\begin{array}{l}\text { Lecturers made } \\
\text { extra effort to } \\
\text { perform better }\end{array}$} & JKUAT & $20 \%$ & $40 \%$ & $30 \%$ & $10 \%$ & 0 & $100 \%$ \\
\hline & & $\begin{array}{l}\text { University of } \\
\text { Nairobi }\end{array}$ & $25 \%$ & $29.2 \%$ & $33.3 \%$ & $12.5 \%$ & 0 & $100 \%$ \\
\hline & & $\begin{array}{l}\text { Kenyatta } \\
\text { University } \\
\end{array}$ & $8.3 \%$ & $33.3 \%$ & $29.2 \%$ & $12.5 \%$ & $16.7 \%$ & $100 \%$ \\
\hline
\end{tabular}


Students' Satisfaction with Module II Academic Programs Offered by Public Universities in

\begin{tabular}{|l|l|l|l|l|l|l|l|l|}
\hline & & Moi University & $30.8 \%$ & $23.1 \%$ & $26.9 \%$ & $11.5 \%$ & $7.7 \%$ & $100 \%$ \\
\cline { 3 - 9 } & MPUC & $13.3 \%$ & $60.0 \%$ & $13.3 \%$ & $13.3 \%$ & 0 & $100 \%$ \\
\hline 6.5 & $\begin{array}{l}\text { Lecturers } \\
\text { respectful }\end{array}$ & JKUAT & $40 \%$ & $50 \%$ & $10 \%$ & 0 & 0 & $100 \%$ \\
\cline { 3 - 9 } & $\begin{array}{l}\text { University of } \\
\text { Nairobi }\end{array}$ & $37.5 \%$ & $45.8 \%$ & $12.5 \%$ & $4.2 \%$ & 0 & $100 \%$ \\
\cline { 3 - 9 } & $\begin{array}{l}\text { Kenyatta } \\
\text { University }\end{array}$ & $37.5 \%$ & $45.8 \%$ & $12.5 \%$ & 0 & $4.2 \%$ & $100 \%$ \\
\cline { 3 - 9 } & Moi University & $34.6 \%$ & $26.9 \%$ & $15.4 \%$ & $3.8 \%$ & $19.2 \%$ & $100 \%$ \\
\cline { 3 - 8 } & MPUC & $26.7 \%$ & $66.7 \%$ & $6.7 \%$ & 0 & 0 & $100 \%$ \\
\hline
\end{tabular}

As shown in Table 4.6., respondents were asked to indicate their position in relation to several key satisfaction elements. There was a general consensus from all the respondents from all the university campuses that lecturers came on time for their classes. A majority of respondents from university of Nairobi, Moi and Kenyatta Universities strongly agreed that their lecturers were knowledgeable and competent in their respective areas. $30 \%$ of respondents from JKUAT were unsure about the competence of their teachers while $33.3 \%$ of their counterparts from Mombasa Polytechnic University College (MPUC) were also neutral. 70\% of respondents from JKUAT agreed that their lecturers were always prepared to teach, with an additional $20 \%$ in strong agreement. On the other end 53.3\% of students from MPUC were impartial about their lecturers' preparation to teach. Majority of respondents from the University of Nairobi were nonpartisan about whether their lecturers made an extra step to make them learn better. Generally a big percentage of the respondents from other university campuses shared the same feeling. A cumulative $93.3 \%$ of respondents from MPUC believed their lecturers were respectful, followed by a cumulative total of $90 \%$ from JKUAT.

\subsubsection{Perceived Student satisfaction with University Library and other resources}

The respondents were asked to indicate their views in relation use of university library resources as a key satisfaction element. The results are shown in Table 4.7. 100\% of respondents interviewed from JKUAT agreed that their library staff were friendly and courteous. Only $57.7 \%$ of respondents from MU were in agreement with the statement. On the speed of delivery of library services, a cumulative $50 \%$ of interviewed respondents agreed that the services were fast with $30.8 \%$ remaining neutral. Only $30 \%$ of respondents from JKUAT campus felt that their library had enough resources materials. 20\% of JKUAT's respondents remained neutral, with the remaining $50 \%$ in disagreement. The other respondents from other universities shared the same distribution pattern, except for UON, where a cumulative $66.7 \%$ were in agreement, $29.2 \%$ neutral, and only $4.2 \%$ disagreeing. $38.5 \%$ of

Table 4.7: Use of university library and other resource centers

\begin{tabular}{|c|c|c|c|c|c|c|c|c|}
\hline & Statements & Institution & $\begin{array}{l}\text { Strongly } \\
\text { Agree }\end{array}$ & Agree & Neutral & Disagree & $\begin{array}{l}\text { Strongly } \\
\text { Disagree }\end{array}$ & $\begin{array}{l}\text { Total } \\
\text { Percentage }\end{array}$ \\
\hline \multirow[t]{5}{*}{1.} & \multirow{5}{*}{$\begin{array}{lr}\text { Library staff } & \text { were } \\
\text { friendly } & \text { and } \\
\text { courteous } & \end{array}$} & JKUAT & $70 \%$ & $30 \%$ & 0 & 0 & 0 & $100 \%$ \\
\hline & & $\begin{array}{l}\text { University of } \\
\text { Nairobi }\end{array}$ & $25.0 \%$ & $66.7 \%$ & $8.3 \%$ & 0 & 0 & $100 \%$ \\
\hline & & $\begin{array}{l}\text { Kenyatta } \\
\text { University } \\
\end{array}$ & $37.5 \%$ & $45.8 \%$ & $4.2 \%$ & $8.3 \%$ & $4.2 \%$ & $100 \%$ \\
\hline & & Moi University & $7.7 \%$ & $50.0 \%$ & $23.1 \%$ & $15.4 \%$ & $3.8 \%$ & $100 \%$ \\
\hline & & MPUC & $13.3 \%$ & $53.3 \%$ & $26.7 \%$ & $6.7 \%$ & 0 & $100 \%$ \\
\hline \multirow[t]{5}{*}{2.} & \multirow{5}{*}{$\begin{array}{l}\text { Library services } \\
\text { were quick }\end{array}$} & JKUAT & $50 \%$ & $20 \%$ & $30 \%$ & 0 & 0 & $100 \%$ \\
\hline & & $\begin{array}{l}\text { University of } \\
\text { Nairobi }\end{array}$ & $4.2 \%$ & $62.5 \%$ & 29.2 & $4.2 \%$ & $\overline{0}$ & $100 \%$ \\
\hline & & $\begin{array}{l}\text { Kenyatta } \\
\text { University } \\
\end{array}$ & $12.5 \%$ & $54.2 \%$ & $25.0 \%$ & $8.3 \%$ & 0 & $100 \%$ \\
\hline & & Moi University & $3.8 \%$ & $46.2 \%$ & $30.8 \%$ & 7.7 & $11.5 \%$ & $100 \%$ \\
\hline & & MPUC & $20.0 \%$ & $46.7 \%$ & $13.3 \%$ & $13.3 \%$ & $6.7 \%$ & $100 \%$ \\
\hline \multirow[t]{5}{*}{3.} & \multirow{5}{*}{$\begin{array}{lr}\text { Library } & \text { has } \\
\text { adequate } & \text { resource } \\
\text { materials } & \end{array}$} & JKUAT & $10 \%$ & $20 \%$ & $20 \%$ & $30 \%$ & $20 \%$ & $100 \%$ \\
\hline & & $\begin{array}{l}\text { University of } \\
\text { Nairobi }\end{array}$ & $4.2 \%$ & $62.5 \%$ & $29.2 \%$ & $4.2 \%$ & 0 & $100 \%$ \\
\hline & & $\begin{array}{l}\text { Kenyatta } \\
\text { University } \\
\end{array}$ & $8.3 \%$ & $25.0 \%$ & $33.3 \%$ & $12.5 \%$ & $20.8 \%$ & $100 \%$ \\
\hline & & Moi University & 0 & $34.6 \%$ & $19.2 \%$ & $23.1 \%$ & $23.1 \%$ & $100 \%$ \\
\hline & & MPUC & $13.3 \%$ & $33.3 \%$ & $26.7 \%$ & $20.0 \%$ & $6.7 \%$ & $100 \%$ \\
\hline \multirow[t]{4}{*}{4.} & \multirow{4}{*}{$\begin{array}{l}\text { Library operating } \\
\text { hours convenient }\end{array}$} & JKUAT & $10 \%$ & $40 \%$ & $30 \%$ & 10 & 10 & $100 \%$ \\
\hline & & $\begin{array}{l}\text { University of } \\
\text { Nairobi }\end{array}$ & $29.2 \%$ & $50 \%$ & $16.7 \%$ & $4.2 \%$ & 0 & $100 \%$ \\
\hline & & $\begin{array}{l}\text { Kenyatta } \\
\text { University } \\
\end{array}$ & $25 \%$ & $41.7 \%$ & $20.8 \%$ & $4.2 \%$ & $8.3 \%$ & $100 \%$ \\
\hline & & Moi University & $15.4 \%$ & $15.4 \%$ & $38.5 \%$ & $11.5 \%$ & $19.2 \%$ & $100 \%$ \\
\hline
\end{tabular}


Students' Satisfaction with Module II Academic Programs Offered by Public Universities in

\begin{tabular}{|c|c|c|c|c|c|c|c|c|}
\hline & & MPUC & $26.7 \%$ & $40.0 \%$ & $13.3 \%$ & $13.3 \%$ & $6.7 \%$ & $100 \%$ \\
\hline \multirow[t]{5}{*}{5.} & \multirow{5}{*}{$\begin{array}{l}\text { It is easy to access } \\
\text { online journals }\end{array}$} & JKUAT & $10 \%$ & $10 \%$ & $20 \%$ & $40 \%$ & $20 \%$ & $100 \%$ \\
\hline & & $\begin{array}{l}\text { University of } \\
\text { Nairobi }\end{array}$ & $20.8 \%$ & $58.3 \%$ & $20.8 \%$ & 0 & 0 & $100 \%$ \\
\hline & & $\begin{array}{l}\text { Kenyatta } \\
\text { University }\end{array}$ & $12.5 \%$ & $25 \%$ & $16.7 \%$ & $33.3 \%$ & $12.5 \%$ & $100 \%$ \\
\hline & & Moi University & 0 & $15.4 \%$ & $15.4 \%$ & $19.2 \%$ & $50 \%$ & $100 \%$ \\
\hline & & MPUC & $26.7 \%$ & $6.7 \%$ & $20.7 \%$ & $33.3 \%$ & $13.3 \%$ & $100 \%$ \\
\hline \multirow[t]{5}{*}{6.} & \multirow{5}{*}{$\begin{array}{l}\text { Computer lab is } \\
\text { well stocked, with } \\
\text { reliable working } \\
\text { computers }\end{array}$} & JKUAT & $10 \%$ & $20 \%$ & $20 \%$ & $10 \%$ & $40 \%$ & $100 \%$ \\
\hline & & $\begin{array}{l}\text { University of } \\
\text { Nairobi }\end{array}$ & $29.2 \%$ & $50.0 \%$ & $20.8 \%$ & 0 & $\overline{0}$ & $100 \%$ \\
\hline & & \begin{tabular}{|l|} 
Kenyatta \\
University \\
\end{tabular} & $20.8 \%$ & $33.3 \%$ & $25.0 \%$ & $12.5 \%$ & $8.3 \%$ & $100 \%$ \\
\hline & & Moi University & $3.8 \%$ & $7.7 \%$ & $15.4 \%$ & $11.5 \%$ & $61.5 \%$ & $100 \%$ \\
\hline & & MPUC & 0 & $33.3 \%$ & $26.7 \%$ & $26.7 \%$ & $13.3 \%$ & $100 \%$ \\
\hline
\end{tabular}

respondents from MU were impartial about the convenience of their library operating hours; $30.8 \%$ were in agreement that the hours were convenient, while 30.7 disagreed.

Majority of respondents from other universities felt the library operating hours in their respective campuses was convenient. $60 \%$ of respondents from JKUAT disagreed that they could access online journals through their campus library, with $20 \%$ neutral and only $20 \%$ in agreement. Similarly, $69.2 \%$ of respondents from MU disagreed that they could access online journals through their library, with $15.4 \%$ neutral, and an equal number in agreement. At the other extreme, $79.1 \%$ of respondents from UON agreed that they were able to access online journals through their campus library, with the remaining $20.8 \%$ neutral. Similarly, a cumulative total of $79.2 \%$ of respondents from UON agreed that their computer laboratory was well stocked, with reliable working computers, with the rest $20.8 \%$ remaining neutral.

At the other end of the continuum, we have $73.0 \%$ of MU respondents disagreeing that their libraries had enough reliable computers, with $15.4 \%$ neutral, and only $11.5 \%$ in agreement. This is closely followed by JKUAT where a cumulative total of 50\% disagreed that they had enough reliable computers, with $20 \%$ neutral and only $30 \%$ in agreement. It becomes evident from the analysis that respondents from MU expressed the most dissatisfaction as far as the use of library and other resource centers is concerned.

\subsubsection{Perceived Student satisfaction with University Facilities, furniture and other equipment}

Table 4.8: University facilities, furniture and other equipment

\begin{tabular}{|c|c|c|c|c|c|c|c|c|}
\hline & Statements & Institution & $\begin{array}{l}\text { Strongly } \\
\text { Agree }\end{array}$ & Agree & Neutral & Disagree & $\begin{array}{l}\text { Strongly } \\
\text { Disagree }\end{array}$ & $\begin{array}{l}\text { Total } \\
\text { Percentage }\end{array}$ \\
\hline \multirow[t]{5}{*}{1.} & \multirow{5}{*}{$\begin{array}{l}\text { The university has } \\
\text { up to date } \\
\text { equipment }\end{array}$} & JKUAT & $10 \%$ & $20 \%$ & $60 \%$ & $10 \%$ & 0 & $100 \%$ \\
\hline & & $\begin{array}{l}\text { University of } \\
\text { Nairobi }\end{array}$ & $12.5 \%$ & $75 \%$ & $12.5 \%$ & 0 & 0 & $100 \%$ \\
\hline & & $\begin{array}{l}\text { Kenyatta } \\
\text { University }\end{array}$ & $8.3 \%$ & $54.2 \%$ & $20.8 \%$ & $8.3 \%$ & $8.3 \%$ & $100 \%$ \\
\hline & & Moi University & $3.8 \%$ & $7.7 \%$ & $38.5 \%$ & $15.4 \%$ & $34.6 \%$ & $100 \%$ \\
\hline & & MPUC & 0 & $40.0 \%$ & $46.7 \%$ & $6.7 \%$ & $6.7 \%$ & $100 \%$ \\
\hline \multirow[t]{5}{*}{2.} & \multirow{5}{*}{$\begin{array}{l}\text { The lecture halls are } \\
\text { always clean } \\
\text { and neatly arranged }\end{array}$} & JKUAT & $40 \%$ & $40 \%$ & $20 \%$ & 0 & 0 & $100 \%$ \\
\hline & & $\begin{array}{l}\text { University of } \\
\text { Nairobi }\end{array}$ & 12.5 & 70.8 & $16.7 \%$ & $\overline{0}$ & 0 & $100 \%$ \\
\hline & & \begin{tabular}{|l|} 
Kenyatta \\
University \\
\end{tabular} & $20.8 \%$ & $50.0 \%$ & $16.7 \%$ & $12.5 \%$ & 0 & $100 \%$ \\
\hline & & Moi University & $19.2 \%$ & $38.5 \%$ & $23.1 \%$ & $11.5 \%$ & $7.7 \%$ & $100 \%$ \\
\hline & & MPUC & $6.7 \%$ & $46.7 \%$ & 0 & $26.7 \%$ & $20.0 \%$ & $100 \%$ \\
\hline \multirow[t]{5}{*}{3.} & \multirow{5}{*}{$\begin{array}{l}\text { The lecture halls are } \\
\text { well lit for } \\
\text { Conducive for } \\
\text { learning }\end{array}$} & JKUAT & $50 \%$ & $40 \%$ & $10 \%$ & 0 & 0 & $100 \%$ \\
\hline & & $\begin{array}{l}\text { University of } \\
\text { Nairobi }\end{array}$ & $29.2 \%$ & $62.5 \%$ & $8.3 \%$ & 0 & 0 & $100 \%$ \\
\hline & & $\begin{array}{l}\text { Kenyatta } \\
\text { University } \\
\end{array}$ & $37.5 \%$ & $45.8 \%$ & $12.5 \%$ & $4.2 \%$ & $\overline{0}$ & $100 \%$ \\
\hline & & Moi University & $23.1 \%$ & $42.3 \%$ & $15.4 \%$ & $11.5 \%$ & $7.7 \%$ & $100 \%$ \\
\hline & & MPUC & $13.3 \%$ & $66.7 \%$ & $6.7 \%$ & $13.3 \%$ & 0 & $100 \%$ \\
\hline \multirow[t]{5}{*}{4.} & \multirow{5}{*}{$\begin{array}{l}\text { Lecture rooms and } \\
\text { furniture are } \\
\text { comfortable }\end{array}$} & JKUAT & $60 \%$ & $20 \%$ & $20 \%$ & 0 & 0 & $100 \%$ \\
\hline & & $\begin{array}{l}\text { University of } \\
\text { Nairobi }\end{array}$ & $16.7 \%$ & $45.8 \%$ & $33.3 \%$ & $4.2 \%$ & $\overline{0}$ & $100 \%$ \\
\hline & & $\begin{array}{l}\text { Kenyatta } \\
\text { University }\end{array}$ & $25 \%$ & $54.2 \%$ & $16.7 \%$ & $4.2 \%$ & 0 & $100 \%$ \\
\hline & & Moi University & $15.4 \%$ & $19.2 \%$ & $30.8 \%$ & $15.4 \%$ & $19.2 \%$ & $100 \%$ \\
\hline & & MPUC & $13.3 \%$ & $33.3 \%$ & $40.0 \%$ & $13.3 \%$ & 0 & $100 \%$ \\
\hline \multirow[t]{2}{*}{5.} & \multirow{2}{*}{$\begin{array}{l}\text { The audio-visual } \\
\text { teaching aids were }\end{array}$} & JKUAT & $10 \%$ & $10 \%$ & $60 \%$ & $10 \%$ & $10 \%$ & $100 \%$ \\
\hline & & University of & $12.5 \%$ & $41.7 \%$ & $33.3 \%$ & $12.5 \%$ & 0 & $100 \%$ \\
\hline
\end{tabular}




\begin{tabular}{|c|c|c|c|c|c|c|c|c|}
\hline \multirow[t]{4}{*}{ 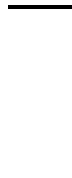 } & \multirow[t]{4}{*}{ sufficient } & Nairobi & & & & & & \\
\hline & & $\begin{array}{l}\text { Kenyatta } \\
\text { University }\end{array}$ & $8.3 \%$ & $25 \%$ & $16.7 \%$ & $20.8 \%$ & $29.2 \%$ & $100 \%$ \\
\hline & & Moi University & $15.4 \%$ & $15.4 \%$ & $15.4 \%$ & $15.4 \%$ & $38.5 \%$ & $100 \%$ \\
\hline & & MPUC & 0 & $26.7 \%$ & $40.0 \%$ & $26.7 \%$ & $6.7 \%$ & $100 \%$ \\
\hline \multirow[t]{5}{*}{6.} & \multirow{5}{*}{$\begin{array}{l}\text { The university's } \\
\text { physical facilities } \\
\text { are visually } \\
\text { appealing }\end{array}$} & JKUAT & $20 \%$ & $40 \%$ & $30 \%$ & $10 \%$ & 0 & $100 \%$ \\
\hline & & $\begin{array}{l}\text { University of } \\
\text { Nairobi }\end{array}$ & $4.2 \%$ & $75.0 \%$ & $20.8 \%$ & 0 & $\overline{0}$ & $100 \%$ \\
\hline & & $\begin{array}{l}\text { Kenyatta } \\
\text { University }\end{array}$ & $4.2 \%$ & $62.5 \%$ & $8.3 \%$ & $20.8 \%$ & $4.2 \%$ & $100 \%$ \\
\hline & & Moi University & $23.1 \%$ & $15.4 \%$ & $11.5 \%$ & $11.5 \%$ & $38.5 \%$ & $100 \%$ \\
\hline & & MPUC & $6.7 \%$ & $46.7 \%$ & $26.7 \%$ & 0 & $20.0 \%$ & $100 \%$ \\
\hline
\end{tabular}

Table 4.8 shows the views of respondents pertaining to their campus facilities, furniture and other equipment. $60 \%$ of respondents from JKUAT remained neutral on whether their campus had up-to-date equipment; with $30 \%$ in agreement, and the remaining $10 \%$ disagreeing. A cumulative $87.5 \%$ of respondents from UON felt that their campus had up-to-date equipment, with the remaining $12.5 \%$ being impartial. There was some general agreement that lecture halls were always clean and neatly arranged from respondents from all the university campuses represented. The only difference was with respondents from MPUC where a cumulative $46.7 \%$ were in disagreement that their lecture facilities were always clean. In terms of furniture and room comfort, JKUAT ranked highest with a cumulative $80 \%$ in agreement, and $20 \%$ neutral. Respondents from MU were torn in the middle, with $30.8 \%$ neutral, and $34.6 \%$ agreeing and disputing respectively. $60 \%$ of respondents from JKUAT were not sure their campus had sufficient audio-visual teaching aids, with $20 \%$ in agreement and dispute respectively. MU and KU had $53.9 \%$ and $50 \%$ of their respective respondents disagreeing that their university campuses had sufficient teaching audio-visual aids. 50\% of respondents from MU were not happy about the physical appearance of their campus, with a total of $38.5 \%$ in agreement, and $11.5 \%$ neutral. Majority of respondents from other campuses liked the appearance of their campuses.

Table 4.8.1: Extra Payment to use varsity facility and equipment

\begin{tabular}{|c|c|c|c|c|c|c|}
\hline \multirow{4}{*}{$\begin{array}{l}\text { Did you pay anything } \\
\text { extra to use the university } \\
\text { facilities or equipment? }\end{array}$} & \multicolumn{5}{|c|}{ Which universities are you enrolled? } & \multirow[t]{2}{*}{ Total } \\
\hline & JKUAT & $\begin{array}{l}\text { University } \\
\text { Nairobi }\end{array}$ & of $\begin{array}{l}\text { Kenyatta } \\
\text { university }\end{array}$ & Moi university & MPUC & \\
\hline & yes & $4.2 \%$ & $16.7 \%$ & $38.5 \%$ & $13.3 \%$ & $17.2 \%$ \\
\hline & $100.0 \%$ & $95.8 \%$ & $83.3 \%$ & $61.5 \%$ & $86.7 \%$ & $82.8 \%$ \\
\hline Total & $100.0 \%$ & $100.0 \%$ & $100.0 \%$ & $100.0 \%$ & $100.0 \%$ & $100.0 \%$ \\
\hline
\end{tabular}

According to Table 4.8.1 above, 38.5\% of respondents from Moi University had to make extra payments to access use of university facilities/equipment. $100 \%$ of respondents from JKUAT disagreed that they had to make extra payments to use varsity resources.

Table 4.8.2: Complaints

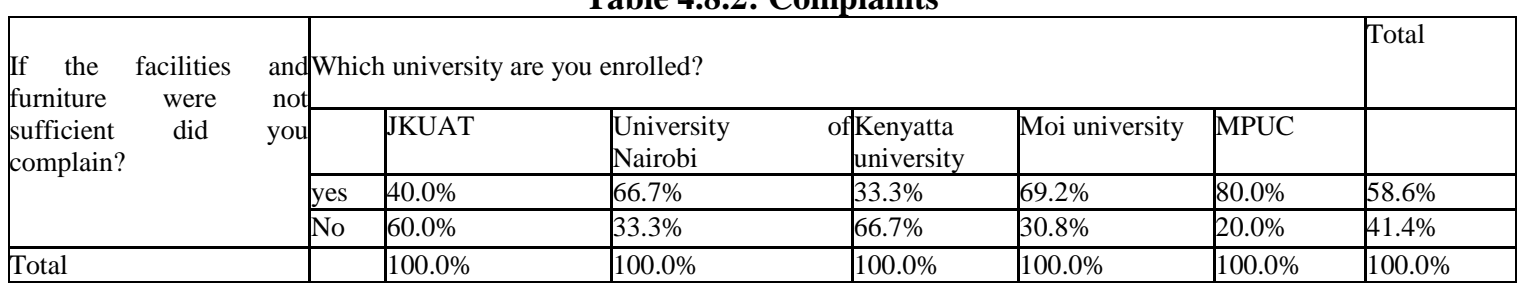

According to Table 4.8.2, MPUC had the highest rate of complaints, followed closely by Moi and UON. On the other extreme, Kenyatta University registered the least number of complaints.

Table 4.8.3: Response to Complaints

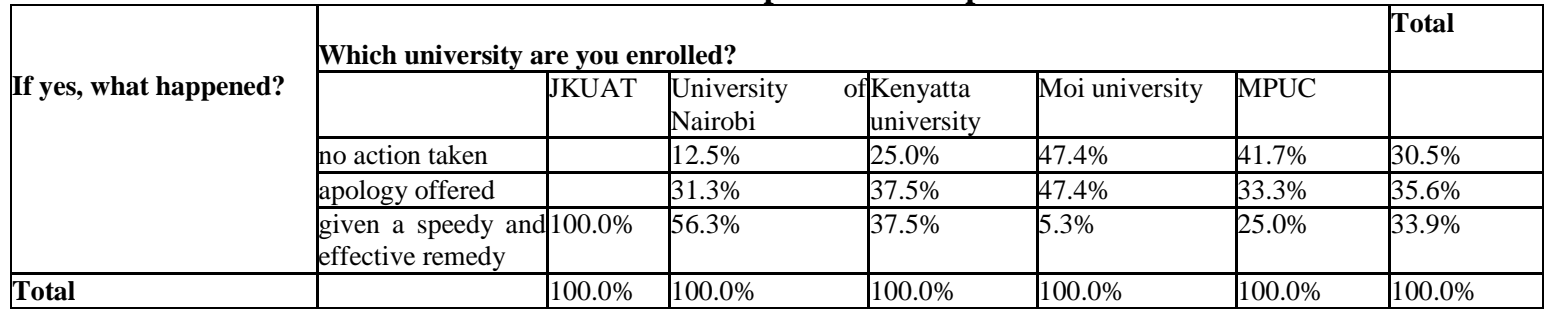


According to Table 4.8.3 above, University of Nairobi had the highest response rate to complaints. $47.4 \%$ of complaints raised by respondents from Moi University were not given any response, with an equal percentage getting apologies.

\subsubsection{Perceived Student satisfaction with University Tuition Costs}

Table 4.9: Tuition and Fees Payment process

\begin{tabular}{|c|c|c|c|c|c|c|c|c|}
\hline & Statements & Institution & $\begin{array}{l}\text { Strongly } \\
\text { Agree }\end{array}$ & Agree & Neutral & Disagree & $\begin{array}{l}\text { Strongly } \\
\text { Disagree }\end{array}$ & $\begin{array}{l}\text { Total } \\
\text { Percentage }\end{array}$ \\
\hline \multirow[t]{5}{*}{1.} & \multirow{5}{*}{$\begin{array}{lr}\text { The } & \text { university } \\
\text { Finance } & \text { and } \\
\text { Accounts } & \text { staff } \text { were } \\
\text { courteous } & \text { and } \\
\text { helpful. } & \\
\text { hell }\end{array}$} & JKUAT & $20 \%$ & $50 \%$ & $\overline{0}$ & $10 \%$ & $20 \%$ & $100 \%$ \\
\hline & & $\begin{array}{l}\text { University of } \\
\text { Nairobi }\end{array}$ & $16.7 \%$ & $54.2 \%$ & $25 \%$ & $4.2 \%$ & 0 & $100 \%$ \\
\hline & & $\begin{array}{l}\text { Kenyatta } \\
\text { University }\end{array}$ & $20.8 \%$ & $62.5 \%$ & $12.5 \%$ & $4.2 \%$ & $\overline{0}$ & $100 \%$ \\
\hline & & Moi University & $46.2 \%$ & $26.9 \%$ & $19.2 \%$ & 0 & $7.7 \%$ & $100 \%$ \\
\hline & & $\overline{\text { MPUC }}$ & $13.3 \%$ & $\overline{40.0 \%}$ & $6.7 \%$ & $20.0 \%$ & $20.0 \%$ & $100 \%$ \\
\hline \multirow[t]{5}{*}{2.} & \multirow{5}{*}{$\begin{array}{l}\text { The Fees payment } \\
\text { process was straight } \\
\text { forward and smooth. }\end{array}$} & JKUAT & $30 \%$ & $60 \%$ & 0 & $10 \%$ & 0 & $100 \%$ \\
\hline & & $\begin{array}{l}\text { University of } \\
\text { Nairobi }\end{array}$ & $20.8 \%$ & $45.8 \%$ & $29.2 \%$ & $4.2 \%$ & $\overline{0}$ & $100 \%$ \\
\hline & & $\begin{array}{l}\text { Kenyatta } \\
\text { University }\end{array}$ & $16.7 \%$ & $50.0 \%$ & $20.8 \%$ & $4.2 \%$ & $8.3 \%$ & $100 \%$ \\
\hline & & Moi University & $34.6 \%$ & $34.6 \%$ & $23.1 \%$ & $\overline{0}$ & $7.7 \%$ & $100 \%$ \\
\hline & & MPUC & 0 & $60 \%$ & $13.3 \%$ & $13.3 \%$ & $13.3 \%$ & $100 \%$ \\
\hline \multirow[t]{5}{*}{3.} & \multirow{5}{*}{$\begin{array}{l}\text { The cost was } \\
\text { reasonable }\end{array}$} & JKUAT & 0 & $40 \%$ & $30 \%$ & $20 \%$ & $10 \%$ & $100 \%$ \\
\hline & & $\begin{array}{l}\text { University of } \\
\text { Nairobi }\end{array}$ & $12.5 \%$ & $45.8 \%$ & $33.3 \%$ & $8.3 \%$ & 0 & $100 \%$ \\
\hline & & $\begin{array}{l}\text { Kenyatta } \\
\text { University }\end{array}$ & $4.2 \%$ & $25.0 \%$ & $20.8 \%$ & $33.3 \%$ & $16.7 \%$ & $100 \%$ \\
\hline & & Moi University & $26.9 \%$ & $26.9 \%$ & $34.6 \%$ & $11.5 \%$ & 0 & $100 \%$ \\
\hline & & MPUC & $6.7 \%$ & $33.3 \%$ & $33.3 \%$ & $20.0 \%$ & $6.7 \%$ & $100 \%$ \\
\hline \multirow[t]{5}{*}{4.} & \multirow{5}{*}{$\begin{array}{l}\text { I felt that I was } \\
\text { getting good value } \\
\text { for my money }\end{array}$} & JKUAT & $20 \%$ & $10 \%$ & $50 \%$ & $10 \%$ & $10 \%$ & $100 \%$ \\
\hline & & $\begin{array}{l}\text { University of } \\
\text { Nairobi }\end{array}$ & $16.7 \%$ & $33.3 \%$ & $41.7 \%$ & $8.3 \%$ & 0 & $100 \%$ \\
\hline & & $\begin{array}{l}\text { Kenyatta } \\
\text { University }\end{array}$ & $12.5 \%$ & $37.5 \%$ & $20.8 \%$ & $25.0 \%$ & $4.2 \%$ & $100 \%$ \\
\hline & & Moi University & $26.9 \%$ & $34.6 \%$ & $15.4 \%$ & $11.5 \%$ & $11.5 \%$ & $100 \%$ \\
\hline & & MPUC & $6.7 \%$ & $13.3 \%$ & $46.7 \%$ & $33.3 \%$ & 0 & $100 \%$ \\
\hline \multirow[t]{5}{*}{5.} & \multirow{5}{*}{$\begin{array}{l}\text { I would strongly } \\
\text { recommend friends } \\
\text { and family to join } \\
\text { my institution }\end{array}$} & JKUAT & $30 \%$ & $20 \%$ & 40 & $10 \%$ & 0 & $100 \%$ \\
\hline & & $\begin{array}{l}\text { University of } \\
\text { Nairobi }\end{array}$ & $29.2 \%$ & $45.8 \%$ & $12.5 \%$ & $8.3 \%$ & $4.2 \%$ & $100 \%$ \\
\hline & & $\begin{array}{l}\text { Kenyatta } \\
\text { University }\end{array}$ & $12.5 \%$ & $58.3 \%$ & $12.5 \%$ & $12.5 \%$ & $4.2 \%$ & $100 \%$ \\
\hline & & Moi University & $26.9 \%$ & $34.6 \%$ & $23.1 \%$ & 0 & $15.4 \%$ & $100 \%$ \\
\hline & & MPUC & $6.7 \%$ & $40.0 \%$ & $26.7 \%$ & $13.3 \%$ & $13.3 \%$ & $100 \%$ \\
\hline \multirow[t]{5}{*}{6.} & \multirow{5}{*}{$\begin{array}{l}\text { I'm very satisfied } \\
\text { with the overall cost } \\
\text { of services offered } \\
\text { at my school }\end{array}$} & JKUAT & $30 \%$ & $20 \%$ & $20 \%$ & $20 \%$ & $10 \%$ & $100 \%$ \\
\hline & & $\begin{array}{l}\text { University of } \\
\text { Nairobi }\end{array}$ & $16.7 \%$ & $41.7 \%$ & $25.0 \%$ & $12.5 \%$ & $4.2 \%$ & $100 \%$ \\
\hline & & $\begin{array}{l}\text { Kenyatta } \\
\text { University }\end{array}$ & $4.2 \%$ & $45.8 \%$ & $29.2 \%$ & $20.8 \%$ & 0 & $100 \%$ \\
\hline & & Moi University & $23.1 \%$ & $26.9 \%$ & $26.9 \%$ & $15.4 \%$ & $7.7 \%$ & $100 \%$ \\
\hline & & MPUC & $6.7 \%$ & $6.7 \%$ & $60.0 \%$ & $13.3 \%$ & $13.3 \%$ & $100 \%$ \\
\hline
\end{tabular}

\subsection{Satisfaction variables that need to be addressed to improve students' satisfaction}

From the data analysis, there tended to be general agreement and disagreement over majority of issues. It is also evident from the above tables that some rare cases arose when satisfaction levels in one satellite campus deviated so much from the rest. The researcherss treated variables that respondents were generally not in agreement or disagreement, i.e. with varied responses, as the contentious issues. The researchers concluded that these issues had direct relationship with students' overall satisfaction and needed to be well addressed by the various campuses. From Table 4.7, it is evident that there was lack of consensus on whether libraries were well stocked with adequate resource materials. Except for respondents from the University of Nairobi, most of the respondents were of the opinion that their libraries were inadequately stocked. Additionally, most respondents concurred that it was not easy to access online journals from their campus portals. Furthermore, it's evident that computer labs from most campuses lacked enough reliable computers. Audio-visual teaching resources in most campuses were also inadequate. 


\section{1: $\quad$ Summary}

\section{Summary, Conclusions And Recommendations}

From the study findings, students were generally satisfied with the services offered by the various campuses of public universities in Mombasa. There was a general consensus that the lecture delivery process across the various satellite campuses was flawless, and was conducted by experienced qualified personnel. There were minor differences in perceived levels of lecturer competence noted between members of various varsities. The findings further reveals that as much as the campuses offered good customer services at their libraries, plus the convenient timings for library use, the libraries were not fully stocked-up with enough learning resources. It's also worth noting that respondents from Moi University particularly were not comfortable with the operating time of their campus library, which they found inconveniencing. There was consensus agreement on access of online journals through university portals; the respondents felt that much needed to be done to allow for ease of access to online study journals

\section{3: $\quad$ Conclusions}

From the data analysis done, it is evident that lecturers from all the campuses involved in the study were generally professional in their dispensation of their duties by keeping time, and going to work when efficiently prepared. In regard to learning resources, respondents from JKUAT and UON found their libraries well stocked with friendly staff. This was not the exact case with the other campuses, where the respondents felt resources needed some attention. Additionally, respondents from UON campus were happy with their campus equipment and facilities. They also found access to online journals easier and reliable, compared to respondents from all the other campuses who found their online access systems unreliable.

Response to customer complaints and issues was very good at JKUAT. Respondents from the campus felt the campus management had done much to ensure that student complaints were being respondent to as fast as possible.

\section{4: $\quad$ Limitations}

The major limitation experienced is that not all students from all the campuses were involved. This was due to unavailability of enough time to interview all key stakeholders and lack of sufficient funding. Additionally, the findings may have been more conclusive had the researchers had more resources to interview more people on a larger scale.

\section{5: $\quad$ Recommendations}

The main objective of the study was to find out the comparative satisfaction levels of students enrolled in the Module II programs of public universities in Mombasa. From the study findings, it is quite evident that students are generally comparatively satisfied with the services offered by public universities in Mombasa. It is however recommended that the universities make the following changes: Update their teaching/learning equipment with modern reliable ones for better service delivery. The study also recommends that the campuses upgrade their online journal systems to ensure easy and reliable access. There is also need across all campuses that they improve their facilities and generally the appearance of their buildings and lecture facilities.

\subsubsection{Recommendations for further research}

The study recommends further research to be conducted to find out the key determinants of students' satisfaction with higher education currently to help universities better structure their service delivery. There is also need to further determine specific satisfaction determinants of mature students, since they make the majority of the students' population in most institutions in Mombasa.

\section{REFERENCES}

[1]. Anderson, E. \& Mittal, V. W. (2000) Strengthening the satisfaction-profit chain. Journal of Service Research, 3(2): pp. 107-120.

[2]. Bitner, M.J., B.H. Booms and L.A. Mohr. 1994. Critical service encounters: The employee's viewpoint. Journal of Marketing 58: 95-106.

[3]. Buzzel, R.D. \& Gale, B. T. (1987). The PIMS Principles: Linking Strategy to Performance. New York: The Free Press.

[4]. Coldwell, J., (2001): Characteristics of a Good Customer Satisfaction Survey. In J. NSheth, A. Parvatiyar \& G. Shainesh, eds., Customer Relationship Management, New Delhi, Tata McGraw-Hill , 2001, pp. 193- 199

[5]. Chepchieng, M.C.(2008) University students' perception of selected institutional factors influencing their attitudes toward campus environment: A comparative study of public and private universities in Kenya; ARC, Division of Research and Extension

[6]. Chacha, N. C.,(2004) Reforming Higher Education in Kenya: Challenges, Lessons and Opportunities; Inter-University Council for East Africa, Naivasha, Kenya

[7]. DeWitt, T. and M.K. Brady. 2003. Rethinking service recovery strategies: the effect of rapport on consumer response to service failure. Journal of Service Research. 6 (2): 193-207.

[8]. Fornell C., Wernerfelt, B.: (1998). A model for consumer complaint management. Mark. Sci., 7(3):271-286.

[9]. Gundersen, M. G., Heide, M. \& Olsson, U. H., (1996): Hotel Guest satisfaction among Business Travellers: What Are the Important Factors? The Cornell Hotel and Restaurant Administration Quarterly, :37(2): 72-81. 
[10]. Hansemark, O. C. \& Albinsson, M. (2004) Customer satisfaction and retention: the experiences of individual employees. Managing Service Quality, 14(1): pp. 40-57.

[11]. Harvey, L. (1995). Student satisfaction: The New Review of Academic Librarianship. Vol. 1 No.1 pp. 161-173. doi:10.1080/13614539509516728, http://dx.doi.org/10.1080/13614539509516728

[12]. Heskett, J.L., Sasser, W.E. and L.A. Schlesinger. 1997. The Service Profit Chain. The Free Press. NY:NY.

[13]. Hom, W., (2000 ): An Overview of Customer Satisfaction Models: RP Group Proceedings California Community Colleges, USA

[14]. Hoyer, W. D. \& MacInnis, D. J., (2001): Consumer Behaviour. 2nd ed., Boston, Houghton Mifflin Company.

[15]. Johnstone, D. Bruce, (2003): Higher Education Finance and accessibility: Tuition Fees and Student Loans in Sub Saharan Africa: State University of New York at Buffalo, United States

[16]. Kara, A., Lonial, S., Tarim, M., \& Zaim, S. (2005). A paradox of service quality in Turkey. European Business Review. Vol. 17 No. 1 pp. 5-20. doi:10.1108/09555340510576230, http://dx.doi.org/10.1108/09555340510576230

[17]. Keaveney, S.M. (1995) Customer switching behavior in service industries: An exploratory study. Journal of Marketing. 59 (April): 71-82.

[18]. Kiamba, C. (2004). Private sponsored students and other income-generating activities at the University of Nairobi. Journal of Higher Education in Africa. 2(2), 53-73.

[19]. Kigotho, W. ( 1999). "Nairobi Gets Tough on Graduate Loans" The Times Higher Education

[20]. Kimani, S.W.,, Kagira, E.K., Kendi, L.,(2011) Comparative Analysis of Business Students' Perceptions of Service Quality Offered in Kenyan Universities; International Journal of Business Administration Vol. 2, No. 1

[21]. Kong, M., \& Jogaratnam, G. (2007). The influence of culture on Perceptions of Service Employee Behavior. Managing Service Quality. Vol.17. No.3. pp. 275-297. doi:10.1108/09604520710744308, http://dx.doi.org/10.1108/09604520710744308

[22]. Kotler, P., 2000, Marketing Management. 10 $0^{\text {th }}$ ed., New Jersey, Prentice-Hall

[23]. Kotler, P. and Armstrong, G. (2000): Marketing: an introduction, New York: Prentice-Hall

[24]. Marcucci, P., Johnstone, D.B., Ngolovoi, M.,(2006): Higher Educational Cost-Sharing, Dual-Track Tuition Fees, and Higher Educational Access: The East African Experience; IREDU Conference on economics of education, Dijon France

[25]. Marcucci, P N. and Johnstone, D. B., (2007): Tuition Fee Policies in comparative perspective: Theoretical and Political Rationales : Journal of Higher Education Policy and Management, Volume 29 Number 1, , 2007, pp. 25-40.

[26]. Murray, H. G. (1997). Does Evaluation of Teaching lead to improvement of teaching? International Journal for Academic Development. Vol. 2 No. 1 pp. 8-13. doi:10.1080/1360144970020102, http://dx.doi.org/10.1080/1360144970020102

[27]. Ngolovoi, M. (2006). Means testing of student loans in Kenya. Presented at the Comparative and International Higher Education Policy: Issues and Analysis Workshop: University at Albany.

[28]. Otieno, Wycliffe. (2005). Dual Track Tuition in Kenya's Public Universities: A Study of the Circumstances and Conditions Under Which Student Attitudes Towards Cost Sharing Would Change. Prepared for the International Comparative Higher Education Finance and Accessibility Project

[29]. Otieno, W. (2004). Student Loans in Kenya: Past Experiences, Current Hurdles, and Opportunities for the Future; Journal of Higher Education in Africa. 2(2), 75-99.

[30]. Oliver, R.L. (1980): A Cognitive Model of the Antecedents and Consequences of Satisfaction Decisions. Journal of Marketing Research, 17: 460-469

[31]. Oliver, R.,(1997): Satisfaction: A Behavioral Perspective on the Consumer. Boston: McGraw-Hill,

[32]. Oliver, R.,(1999): "Value as Excellence in the Consumption Experience." In M. Holbrook (Ed.), Consumer Value: A Framework for Analysis and Research, 43-62, New York: Routledge.

[33]. Parasuraman, A., Zeithaml, V. A. \& Berry, L. L. (1985). A conceptual model of service quality and its implications for future research. Journal of Marketing, 49(4): pp. 41-50.

[34]. Reichheld, F. (1996) The Loyalty Effect, Harvard Business School Press, Boston, 1996.

[35]. Rust, R. T. \& Zahorik, A. J. (1993) Customer satisfaction, customer retention, and market share. Journal of Marketing Research, 59(2): pp. 193-215.

[36]. Rust, R.T., Danaher, P.J., \& Sajeev, V. (2000). Using Service Quality Data for Competitive Marketing Decisions. International $\begin{array}{llllllll}\text { Journal of } & \text { Services Industry } & \text { Management. Vol. } & \text { 11. } & \text { No. } & \text { pp }\end{array}$ doi:10.1108/09564230010360173, http://dx.doi.org/10.1108/09564230010360173

[37]. Sawyer, A., (2002): “Challenges Facing African Universities." Association of African Universities. Accra, Ghana:

[38]. Sanchez, P. M., Gazquez Abad, J. C., Carrillo, G. M. M., \& Fernandez,R. S. (2007). Effects of service QualityDimensions on Behavioral Purchase Intentions; A study in public sector transport. Managing service quality. Vol. 17. No. 2. pp. 134-151. doi:10.1108/09604520710735164, http://dx.doi.org/10.1108/09604520710735164

[39]. Schlesinger, L. and Heskett, J. (1991) "Breaking the cycle of failure in service", Sloan Management Review, spring, 1991, pp. $17-$ 28.

[40]. Tantakasem, P (2008): Service Quality and the Customer Satisfaction Chain in the Thai Retail Banking Industry. Bangkok University

[41]. Wiklund, P.S. \& Wiklund, H. (1999). Student focused design and improvement of university courses. Managing Service Quality. Vol. 9. No. 6. pp. 434-443. doi:10.1108/09604529910302118, http://dx.doi.org/10.1108/09604529910302118

[42]. Woodhall, Maureen (1992) "Changing Sources and Patterns of Finance for Higher Education: A Review of International Trends." Higher Education in Europe, Vol. 17, No. 1:141-149.

[43]. Woodhall, Maureen (2002) Constructing Knowledge Societies: New Challenges for Tertiary Education. Washington, DC: The World Bank.

[44]. Zairi, M., (2000): Managing Customer Dissatisfaction Through Effective Complaint Management Systems, The TQM Magazine, 12 (5), pp. 331-335.

[45]. Zairi, M., (2000): Managing Customer Satisfaction: A Best Practice Perspective, The TQM Magazine, 12 (6), pp. 389-394.

[46]. Zeithaml, V. A. 2000. Service quality, profitability, and economic worth of customers: What we know and what we need to learn. Journal of the Academy of Marketing Science, 28(1): pp. 67-85. 


\section{APPENDIX I: THE QUESTIONNAIRE}

SECTION A: Lecture Delivery

Please tick one and only one answer for each statement. There are no right or wrong answers to these questions. Just give your opinion.

\begin{tabular}{|c|c|c|c|c|c|}
\hline \multirow[t]{3}{*}{ Statement } & \multicolumn{5}{|c|}{ Agreement } \\
\hline & $\begin{array}{l}\text { Strongly } \\
\text { Agree }\end{array}$ & Agree & Neutral & Disagree & $\begin{array}{l}\text { Strongly } \\
\text { disagree }\end{array}$ \\
\hline & 1 & 2 & 3 & 4 & 5 \\
\hline \multicolumn{6}{|l|}{ Lecturers came on time. } \\
\hline \multicolumn{6}{|c|}{ Lecturers came fully prepared to deliver. } \\
\hline \multicolumn{6}{|c|}{ I was treated fairly. } \\
\hline \multicolumn{6}{|c|}{ Lecturers were knowledgeable and competent } \\
\hline \multicolumn{6}{|c|}{$\begin{array}{l}\text { Lecturers went out of their way to make sure I got what } \\
\text { I needed. }\end{array}$} \\
\hline \multicolumn{6}{|l|}{ Lecturers were respectful. } \\
\hline Other & & & & & \\
\hline
\end{tabular}

SECTION B: University Library and other resource centers

Please tick one and only one answer for each statement. There are no right or wrong answers to these questions.

Just give your opinion.

\begin{tabular}{|l|l|l|l|l|l|}
\hline \multirow{2}{*}{ Statement } & Agreement & Neutral & Disagree & $\begin{array}{l}\text { Strongly } \\
\text { disagree }\end{array}$ \\
\cline { 2 - 6 } & $\begin{array}{l}\text { Strongly } \\
\text { Agree }\end{array}$ & Agree & & & 5 \\
\hline & 1 & 2 & 3 & 4 & \\
\hline The library staff are friendly and courteous & & & & & \\
\hline The library services are quick/fast & & & & & \\
\hline It has available resource materials & & & & & \\
\hline The operating hours are convenient for me & & & & \\
\hline It is easy to access online journals & & & & & \\
\hline $\begin{array}{l}\text { The computer lab is well stocked, with reliable and } \\
\text { working computers }\end{array}$ & & & & & \\
\hline
\end{tabular}

\section{SECTION C: University facilities, furniture and other equipment}

Please tick one and only one answer for each statement. There are no right or wrong answers to these questions. Just give your opinion.

\begin{tabular}{|c|c|c|c|c|c|}
\hline \multirow[t]{3}{*}{ Statement } & \multicolumn{5}{|c|}{ Agreement } \\
\hline & $\begin{array}{l}\text { Strongly } \\
\text { Agree }\end{array}$ & Agree & Neutral & Disagree & $\begin{array}{l}\begin{array}{l}\text { Strongly } \\
\text { disagree }\end{array} \\
\text { dis }\end{array}$ \\
\hline & 1 & 2 & 3 & 4 & \\
\hline \multicolumn{6}{|l|}{ The university has up to date equipment } \\
\hline \multicolumn{6}{|c|}{ The lecture halls are always clean and Neatly arranged. } \\
\hline \multirow{2}{*}{\multicolumn{6}{|c|}{$\begin{array}{l}\text { The lecture halls are well lit for Conducive for learning } \\
\text { Lecture rooms and furniture are comfortable. }\end{array}$}} \\
\hline \multicolumn{2}{|c|}{ Lecture rooms and furniture are comfortable. } & & & & \\
\hline \multicolumn{6}{|l|}{$\begin{array}{l}\text { The audio-visual teaching aids were } \\
\text { Sufficient }\end{array}$} \\
\hline \multicolumn{6}{|l|}{$\begin{array}{l}\text { The university's physical facilities are visually } \\
\text { appealing }\end{array}$} \\
\hline Q1. Did you pay anything extra to use & rersity fa & $\mathrm{s}$ or eq & & Yes [ & No \\
\hline
\end{tabular}

Q3. If yes, what happened next?
No action taken
Offered an apology
Given a speedy and effective remedy 
SECTION D: Tuition and Fees Payment process

Please tick one and only one answer for each statement. There is no right or wrong answer to these questions. Just give your opinion.

\begin{tabular}{|c|c|c|c|c|c|}
\hline \multirow[t]{3}{*}{ Statement } & \multicolumn{5}{|c|}{ Agreement } \\
\hline & $\begin{array}{l}\text { Strongly } \\
\text { Agree }\end{array}$ & Agree & Neutral & Disagree & $\begin{array}{l}\text { Strongly } \\
\text { disagree }\end{array}$ \\
\hline & 1 & 2 & 3 & 4 & 5 \\
\hline \multicolumn{6}{|l|}{$\begin{array}{l}\text { The university Finance and Accounts staff were } \\
\text { courteous and helpful. }\end{array}$} \\
\hline \multicolumn{6}{|l|}{$\begin{array}{l}\text { The Fees payment process was straight forward and } \\
\text { smooth. }\end{array}$} \\
\hline \multicolumn{6}{|l|}{ The cost was reasonable } \\
\hline \multicolumn{6}{|c|}{ I felt that I was getting good value for my money } \\
\hline \multicolumn{6}{|c|}{$\begin{array}{l}\text { I would strongly recommend friends and family to join } \\
\text { my institution }\end{array}$} \\
\hline $\begin{array}{l}\text { I'm very satisfied by the overall cost of services } \\
\text { offered at my school }\end{array}$ & & & & & \\
\hline
\end{tabular}

SECTION E: Information about yourself

1. Name (optional):

2. Gender: Female $\square$ Male

3. Age:

$18-24$ yrs

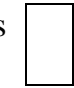

25-34 yrs

4. Marital Status:

Single $\square \quad$ Married

$35-49$ yrs

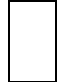

$50 \mathrm{yrs}$ and above

Formal Employment Other (Specify)

6. In which University are you enrolled?

7. Which year of study are you in?

Thank you very much for your information and time.

Benard Nyambaso Omwando 